\title{
The Flawed Mechanics of Mutual Fund Fee Litigation
}

\section{Quinn Curtis \& John Morley†}

In this Article we identify a number of serious mechanical flaws in the statutes and judicial doctrines that govern fee liability for mutual fund managers. Originating in Section 36(b) of the Investment Company Act, mutual fund fee liability allows investors to sue managers for charging fees above a judicially created standard. Commentators have extensively debated whether this liability should exist, but in this Article we focus instead on improving how it actually works. We identify a number of problems. Among other things, statutes and case law (1) impose no penalties to provide deterrence; (2) give recoveries to investors who did not actually pay the relevant fees; (3) treat similar categories of fees differently; (4) create an unusual settlement process that prevents litigants from settling their full claims; (5) expose low-cost advisers to serious litigation risk; (6) exhibit deep confusion about what makes fees excessive; and (7) provide unduly small incentives for plaintiffs' lawyers to litigate meritorious claims. Most of these problems appear to have been accidentally caused by judges' and lawmakers' confusion, rather than deliberate policy choices. We conclude by offering specific ideas for reform.

Introduction .2

I. Introduction to Mutual Funds and Excessive Fee Liability ............................ 4

A. An Introduction to Mutual Funds ..................................................... 4

B. An Introduction to Excessive Fee Liability .................................... 6

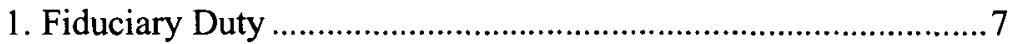

2. Procedural Characteristics ....................................................... 9

3. The Existing Literature ........................................................... 10

4. The State of Excessive Fee Litigation..................................... 11

II. Mechanical Flaws in Excessive Fee Liability ........................................... 13

A. Failure to Provide General Deterrence .......................................... 14

B. Recovery Payments to the Wrong Investors .................................... 15

C. Inconsistent Treatment of Sales Loads and Other Types of Fees ..... 17

D. Awkward Settlement Process ........................................................... 20

E. Exposure of Low-Fee Advisers to Litigation Risk........................... 22

1. The Scrutiny of Low-Fee Advisers ........................................... 22

2. The Difficulty of Summary Judgment ....................................25

3. The Absence of Screening Prior to Summary Judgment ...........26

4. The Empirical Evidence..........................................................26 


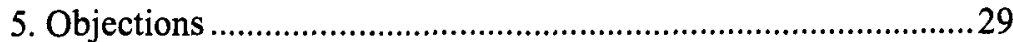

F. Incoherence in the Standard of Liability .............................................30

1. The Imaginary Nature of "Arm's Length Bargaining"................30

2. Undue Fixation on Adviser Profitability ........................................33

G. Overall Inadequacy of Rewards for Plaintiffs' Lawyers .....................34

III. Reforming Excessive Fee Litigation..............................................................37

A. Implement Excessive Fee Suits as Class Actions ................................37

B. Harmonize the Treatment of Load Fees and Other Fees .....................38

C. Add Penalties and Increase Recoveries.............................................39

D. Revise the Standard of Liability..........................................................39

1. Exempt Advisers with Comparatively Low Fees.........................39

2. Sharpening Liability for High-Fee Advisers.................................41

3. A Mechanical Test of Liability? .................................................43

Conclusion

Introduction

This Article identifies and analyzes a number of serious flaws in the mechanics of mutual fund excessive fee liability. Excessive fee liability originates from Section 36(b) of the Investment Company Act and allows mutual fund investors to sue a fund's operators by claiming that the fund's fees are too high. Investors can make this claim even if a fund's fees have been fully and accurately disclosed.

The existing debate about excessive fee liability has focused principally on the abstract question of whether this form of liability ought to exist in the first place. ${ }^{1}$ It asks whether the mutual fund market is sufficiently competitive on its own terms or whether some form of price regulation is required. Advocates of excessive fee liability argue that market competition is inadequate, while opponents argue that it is robust. In its focus on the overarching need for excessive fee liability, the existing debate has left the actual form of this liability largely unexamined.

Our goal is to reverse this approach. For the sake of argument, we accept the notion that excessive fee liability is desirable in some form, and we focus instead on understanding and improving the form it has actually taken. What we discover is deeply troubling. The procedures that structure excessive fee litigation are profoundly flawed. If excessive fee liability is ever to have any meaningful impact, these flaws must be fixed.

$\dagger$ Quinn Curtis is an Associate Professor of Law at the University of Virginia School of Law. John Morley is an Associate Professor of Law at Yale Law School. We thank Kwon-Yong Jin for outstanding research assistance and Dahlia Mignouna for excellent editorial work.

1. See infra Part I.B. 
We identify a number of problems. Among other things, statutes and case law (1) impose no penalties to provide deterrence; (2) give recoveries to investors who did not actually pay the relevant fees; (3) treat similar categories of fees differently; (4) create an unusual settlement process that prevents litigants from settling their full claims; (5) expose low-cost advisers to serious litigation risk; (6) exhibit deep confusion about what makes fees excessive; and (7) provide unduly small incentives for plaintiffs' lawyers to litigate meritorious claims. Although some of these flaws are the results of deliberate policy choices in Congress and the courts, most appear to be unintended errors resulting from confusion about how mutual funds operate and how different parts of the law interact.

This topic is important, because mutual funds are the elephants in the room of American finance. They hold more wealth than America's commercial banks, and they comprise about a quarter of American households' financial assets. ${ }^{2}$ These funds are heavily regulated, and excessive fee liability is a major part of mutual fund regulation. In the ten years between 2000 and 2009, about a quarter of all mutual funds became the targets of this kind of litigation. ${ }^{3}$ And excessive fee liability's influence extends well beyond the courtroom. The directors of mutual funds spend much of their time in the boardroom completing paperwork designed to serve as evidence of due diligence and good faith in future excessive fee suits. ${ }^{4}$

Excessive fee liability has thus been a topic of tremendous popular and scholarly debate. Indeed, it may be the most talked-about feature in all of investment management regulation. ${ }^{5}$ This debate reached a crescendo only a few years ago, when the Supreme Court upheld excessive fee liability against a challenge in the lower courts in Jones v. Harris Associates. ${ }^{6}$ At issue, in essence, was whether advisers would be liable for the excessiveness of fees at all. ${ }^{7}$ The case produced a much-discussed disagreement between Judges Frank Easterbrook and Richard Posner in the Seventh Circuit. In the end, the Supreme

2. INV. Co. INST., ICI FACT BOOK, 10 fig.1.2 (2013) (indicating that mutual funds comprise $23 \%$ of Americans' household financial assets); Federal Reserve Statistical Release: Large Commercial Banks (Junc 30, 2013), http://www.federalreserve.gov/releases/lbr/20130630/default.htm (indicating that American commercial banks hold about $\$ 12.6$ trillion in assets).

3. Quinn Curtis \& John Morley, An Empirical Study of Mutual Fund Excessive Fee Litigation: Do the Merits Matter?, 30 J.L. ECON. \& ORG. 275, 277 (2014).

4. One of the factors courts consider in determining whether an adviser should be liable is the independence and conscientiousness of a fund's directors. Directors thus spend a great deal of time creating a record of independence and conscientiousness in their negotiations with advisers. This record is commonly distilled into a document called a "Gartenberg memo," after the Second Circuit opinion that established excessive fee liability. LOIS YUROW ET AL., MUTUAL FUND REGULATION AND COMPLIANCE HANDBOOK $\S 19: 8$ (2013).

5. See infra Part I.B.3 for a review of the literature.

6. Jones v. Harris Assocs. L.P., 559 U.S. 335 (2010).

7. Jones v. Harris Assocs. L.P., 527 F.3d 627 (7th Cir. 2008) (Easterbrook, J., granting motion for summary judgment), reh'g denied, 537 F.3d 728, 729 (7th Cir. 2008) (Posner, J., dissenting from denial of rehearing en banc), vacated and remanded, 559 U.S. 335 (2010). 
Court upheld the status quo and maintained excessive fee liability, but the case raised deep questions that remain unresolved.

Our focus on the details of excessive fee liability's implementation may seem narrow, but we believe it is a matter of great importance. Excessive fee liability has been implemented so poorly that the questions about its abstract value are almost beside the point. Without serious reform of its mechanics, excessive fee liability cannot serve as a useful policy tool--regardless of whether it ought to.

Our broadest goal is thus to try and make excessive fee liability work. Like almost everyone who thinks seriously about the mutual fund industry, we are concerned about the stubborn persistence of funds whose fees clearly exceed those of their peers, and we wish for some way to address this problem. Although we have expressed skepticism in the past about whether excessive fee liability is truly the best solution, ${ }^{8}$ we acknowledge that excessive fee liability retains substantial political support and that it will most likely remain an enduring part of the regulatory landscape in spite of its many limitations. We therefore write this Article in an attempt to ensure that excessive fee liability achieves the greatest possible benefit at the lowest possible cost. This Article's contribution is original because, even though a great many commentators have written about excessive fee liability's overall value, the mechanical flaws we identify have received little attention.

Part I introduces mutual funds and the basics of excessive fee liability. Part II then discusses each of the various mechanical flaws we have identified. Part III closes with recommendations for fixing these problems.

\section{Introduction to Mutual Funds and Excessive Fee Liability}

\section{A. An Introduction to Mutual Funds}

Mutual funds are commonly defined as pools of stocks, bonds, or other investment securities. Mutual funds often sell shares in these pools to members of the general public, who buy the shares to invest for retirement or other purposes. Because mutual funds sell their shares widely to the general public, they must register with the Securities and Exchange Commission (SEC) and comply with the Investment Company Act of 1940 (ICA). The ICA contains a complex and detailed body of regulation, of which excessive fee liability is one piece. Because mutual funds must register under the ICA, they are known in legal jargon as "registered investment companies."

Like all investment funds, mutual funds adopt a pattern of organization that we have elsewhere called "the separation of funds and managers." In this

8. John Morley \& Quinn Curtis, Taking Exit Rights Seriously: Why Governance and Fee Litigation Don't Work in Mutual Funds, 120 YALE L.J. 84, 139 (2010).

9. John Morley, The Separation of Funds and Managers, 123 YALE L.J. 1228 (2014). 
pattern, mutual funds hold stocks, bonds, and other investment assets, but they have no employees or workers of their own and no operational assets, such as offices or computers. Instead, they receive all of their operational necessities by contract from separately owned outside companies known as "advisers" or "managers." These advisers specialize in the management of mutual funds and other investment vehicles, and their ranks include widely known financial conglomerates such as Fidelity, Vanguard, T. Rowe Price, TIAA-CREF, Goldman Sachs, and Morgan Stanley. These advisers typically make all of the investment decisions in their mutual funds, and they control the funds' marketing strategies. In fact, the advisers are almost always the ones who actually set up the funds. Advisers often operate dozens or even hundreds of funds simultaneously and commonly market the funds under a single brand name. Fidelity, for example, operates many funds under the Fidelity name, including funds that invest in the stock of S\&P 500 companies, municipal debt securities, international stocks, and so on. In exchange for providing managerial services, the advisers charge the funds various fees. It is these fees that are the subject of excessive fee liability.

The ICA attempts to give mutual funds a measure of independence from their advisers, but in practice these funds are almost completely dominated by their advisers. Although in theory directors can terminate their funds' contracts with their advisers and find new advisers, ${ }^{10}$ in practice they almost never do. ${ }^{11}$

This pattern of separation between funds and advisers and domination by advisers may seem odd, but it is common to all of the types of enterprise that most people think of as investment funds - including hedge funds, private equity funds, venture capital funds, and so on. ${ }^{12}$ In fact, this pattern is a large part of what defines a business as an "investment fund" and differentiates it from ordinary operating companies. ${ }^{13}$ This pattern serves important and valuable functions, which we have identified elsewhere. ${ }^{14}$

One of mutual funds' key features is that they allow their shareholders to "redeem" their shares. In other words, shareholders can return their shares to

10. See 15 U.S.C. $\$ 80 \mathrm{a}-15$ (c) (2012).

11. Warren Buffet, the famous investor, expressed the point in his usual colorful style:

Year after year the directors of Fund A select manager A, Fund B directors select manager B, etc. ... in a zombie-like process that makes a mockery of stewardship. Very occasionally, a board will revolt. But for the most part, a monkey will type out a Shakespeare play before an "independent" mutual-fund director will suggest that his fund look at other managers, even if the incumbent manager has persistently delivered substandard performance.

Letter from Warren Buffett to the Shareholders of Berkshire Hathaway Inc. 17 (Feb. 21, 2003), http://www.berkshirehathaway.com/letters/2002pdf.pdf.

12. Morley, supra note 9 , at 1232 .

13. Id.

14. Id. 
the funds and receive in exchange the cash value of the assets that corresponds to each share. Mutual funds allow their shareholders to redeem every day.

Mutual funds are not the only type of investment fund. Some types of investment funds, such as private equity and hedge funds, sell securities only to wealthy individuals and institutions rather than to the general public and therefore do not have to register under the ICA. These funds are thus exempt from excessive fee liability, and we will not discuss them further here.

"Closed-end" funds, another type of investment fund, have to register under the ICA and are subject to excessive fee liability like mutual funds. The primary distinguishing feature of closed-end funds is that, unlike mutual funds, they do not offer redeemable shares. Instead, they offer their shareholders the ability to buy and sell shares on securities exchanges, just as the shares of ordinary companies, such as General Motors and Microsoft, are traded on exchanges. Mutual funds are sometimes known as "open-end" funds to distinguish them from these closed-end funds. "Exchange-traded" funds (ETFs), which have received a great deal of attention in recent years, are simply a special kind of mutual fund. ${ }^{15}$ Closed-end funds and exchange-traded funds are technically subject to excessive fee liability, but they comprise only a small portion of the overall investment fund industry and have not frequently been subjected to excessive fee suits. ${ }^{16}$ We therefore will not discuss them here. We will also ignore private funds, such as hedge funds, private equity funds, and venture capital funds, because these funds are exempt from the Investment Company Act and its excessive fee liability scheme.

\section{B. An Introduction to Excessive Fee Liability}

Excessive fee liability has its roots in Section 36(b) of the ICA. Congress added Section 36(b) to the ICA in 1970 in the Investment Company Amendments Act of $1970 .{ }^{17}$ The Investment Company Amendments Act was a major reform and it made a number of important changes to the ICA in response to a lengthy study of the mutual fund industry by the University of Pennsylvania's Wharton School. ${ }^{18}$ This study expressed concern about the robustness of competition in the mutual fund market and about the ability of mutual fund boards

15. See generally William A. Birdthistle, The Fortunes and Foibles of ExchangeTraded Funds: A Positive Market Response to the Problems of Mutual Funds, 33 DEL. J. CORP. L. 69 (2008) (describing the basic mechanics of exchange-traded funds).

16. Open-end funds hold about fifty times more assets than closed-end funds. INV. Co. INST., supra note 2, at ii. In our efforts to collect data for our study on excessive fee liability, we encountered no excessive fee complaints against exchange-traded funds and only a handful against closed-end funds.

17. Investment Company Amendments Act of 1970, Pub. L. No. 91-547, 84 Stat. 1413.

18. The study was published as WHARTON SCH. OF FIN. \& COMMERCE, A STUDY OF MUTUAL FUNDS, H.R. REP. NO. 87-2274, at 28-36 (1962). 
of directors to negotiate with fund advisers. ${ }^{19}$ The SEC saw Section $36(\mathrm{~b})$ as part of the solution to these perceived problems. ${ }^{20}$

Section 36(b) has two major features: (1) a basic fiduciary duty and (2) a set of procedural and mechanical rules to structure the suits that allege violation of that duty. Section $36(\mathrm{~b})$ is fairly long, so we reproduce the full text in a footnote. $^{21}$

\section{Fiduciary Duty}

Section 36(b) places its first component-the fiduciary duty-at the beginning of the section. It says:

19. Id. at 28-37, 44-52.

20. After the Wharton School published its report, the SEC published a report of its own, calling for the reforms that were ultimately enacted in Section 36(b). SEC. \& EXCH. COMM'N, Public POlicy ImPlications OF InVestment COMPANY GROWTH, H.R. REP No. 89-2337, at 144 (1966), http://sechistorical.org/museum/papers/1960.

21. (b) ... For the purposes of this subsection, the investment adviser of a registered investment company shall be deemed to have a fiduciary duty with respect to the receipt of compensation for services, or of payments of a material nature, paid by such registered investment company, or by the security holders thereof, to such investment adviser or any affiliated person of such investment adviser. An action may be brought under this subsection by the Commission, or by a security holder of such registered investment company on behalf of such company, against such investment adviser, or any affiliated person of such investment adviser, or any other person enumerated in subsection (a) of this section who has a fiduciary duty concerning such compensation or payments, for breach of fiduciary duty in respect of such compensation or payments paid by such registered investment company or by the security holders thereof to such investment adviser or person. With respect to any such action the following provisions shall apply:

(1) It shall not be necessary to allege or prove that any defendant engaged in personal misconduct, and the plaintiff shall have the burden of proving a breach of fiduciary duty.

(2) In any such action approval by the board of directors of such investment company of such compensation or payments, or of contracts or other arrangements providing for such compensation or payments, and ratification or approval of such compensation or payments, or of contracts or other arrangements providing for such compensation or payments, by the shareholders of such investment company, shall be given such consideration by the court as is deemed appropriate under all the circumstances.

(3) No such action shall be brought or maintained against any person other than the recipient of such compensation or payments, and no damages or other relief shall be granted against any person other than the recipient of such compensation or payments. No award of damages shall be recoverable for any period prior to one year before the action was instituted. Any award of damages against such recipient shall be limited to the actual damages resulting from the breach of fiduciary duty and shall in no event exceed the amount of compensation or payments received from such investment company, or the security holders thereof, by such recipient.

(4) This subsection shall not apply to compensation or payments made in connection with transactions subject to section $80 \mathrm{a}-17$ of this title, or rules, regulations, or orders thereunder, or to sales loads for the acquisition of any security issued by a registered investment company.

(5) Any action pursuant to this subsection may be brought only in an appropriate district court of the United States.

(6) No finding by a court with respect to a breach of fiduciary duty under this subsection shall be made a basis (A) for a finding of a violation of this subchapter for the purposes of sections $80 \mathrm{a}-9$ and $80 \mathrm{a}-48$ of this title, section 780 of this title, or section $80 \mathrm{~b}-3$ of this title, or (B) for an injunction to prohibit any person from serving in any of the capacities enumerated in subsection (a) of this section.

15 U.S.C. $\$ 80 \mathrm{a}-35(\mathrm{~b})(2012)$. 
[T] he investment adviser of a registered investment company shall be deemed to have a fiduciary duty with respect to the receipt of compensation for services, or of payments of a material nature, paid by such registered investment company, or by the security holders thereof, to such investment adviser or any affiliated person of such investment adviser. ${ }^{22}$

Importantly, this language does not mention "excessive" fees. It mentions only a fiduciary duty and says nothing about what precisely that duty entails. Thus when Section 36(b) first appeared, the content of this fiduciary duty was anyone's guess. It could have been interpreted to prohibit excessive fees, or it could have been interpreted merely to prohibit fraud in the disclosure of fees.

In 1982, the U.S. Court of Appeals for the Second Circuit addressed this uncertainty by coming down squarely on the side of liability for excessiveness of fees and not just fraud. In Gartenberg v. Merrill Lynch Asset Management, Inc., the Second Circuit held:

[T]he test is essentially whether the fee schedule represents a charge within the range of what would have been negotiated at arm's-length in light of all of the surrounding circumstances. ... To be guilty of a violation of $\S 36(\mathrm{~b}), \ldots$ the adviser must charge a fee that is so disproportionately large that it bears no reasonable relationship to the services rendered and could not have been the product of arm's length bargaining. ${ }^{23}$

Subsequent opinions interpreted Gartenberg as having identified six factors for determining excessive fee liability:

(a) the nature and quality of services provided to fund shareholders; (b) the profitability of the fund to the adviser-manager; (c) fall-out benefits; (d) economies of scale; (e) comparative fee structures; and (f) the independence and conscientiousness of the trustees. ${ }^{24}$

Gartenberg made it clear that even advisers who charge fees below the rates prevailing among similar funds may be subject to liability. ${ }^{25}$ This was a point of great importance, to which we will return below. ${ }^{26}$

The Gartenberg standard was widely accepted in the circuit courts until 2009, when Judge Frank Easterbrook of the Seventh Circuit challenged it in Jones v. Harris Associates L.P. ${ }^{27}$ Easterbrook replaced Gartenberg with a

22. Id.

23. Gartenberg v. Merrill Lynch Asset Mgmt., Inc., 694 F.2d 923, 928 (2d Cir. 1982).

24. Krinsk v. Fund Asset Mgmt., Inc., 875 F.2d 404, 409 (2d Cir. 1989).

25. Gartenberg, 694 F.2d at 929.

26. See infra Part II.E.

27. Jones v. Harris Assocs. L.P., 527 F.3d 627 (7th Cir. 2008). 
standard that would have allowed liability only for fraud or misconduct. ${ }^{28}$ This would have eliminated liability for fees that were merely excessive, so long as they had been fully disclosed. In a dissent from a denial of rehearing en banc, Judge Richard Posner heavily criticized Easterbrook's standard. ${ }^{29}$ Posner advocated maintaining the Gartenberg standard, arguing that it was necessary to address inadequate competition in the mutual fund market. ${ }^{30}$ In March 2010, the Supreme Court vacated Easterbrook's decision and expressly validated Posner's view by adopting the old Second Circuit Gartenberg standard. ${ }^{31}$

\section{Procedural Characteristics}

In addition to imposing the basic "fiduciary duty" noted above, Section 36(b) also contains a set of procedural rules. These rules occupy the bulk of Section 36(b)'s text, and an analysis of them will also occupy the bulk of this Article. First, Section 36(b) allows plaintiffs to initiate suits only in the federal courts. ${ }^{32}$ Section 36 (b) cannot be enforced in state courts. Second, Section 36 (b) confers standing only on mutual fund investors and the SEC, not on the funds themselves. ${ }^{33}$ The SEC has brought only one Section $36(\mathrm{~b})$ suit that we know of. ${ }^{34}$ The SEC has tended instead to regulate fees using other parts of the ICA, perhaps because of the procedural problems with Section 36(b) that we identify. ${ }^{35}$

Although Section 36(b) suits may be initiated by investors and the SEC, they can only be brought on behalf of the funds, not on behalf of investors or the SEC. ${ }^{36}$ This means that recoveries go to the funds, not to investors or the SEC. Section 36(b) suits thus cannot be maintained as class actions and are reminiscent of corporate derivative suits, which are conventionally brought by investors on behalf of corporations. Unlike conventional derivative suits, however, Section 36(b) suits do not involve rights that could be enforced by the funds, since Section 36(b) gives standing only to investors and the SEC. The Supreme Court has therefore held that, unlike conventional derivative suits, Section 36(b) suits are not subject to traditional state law demand require-

28. See id. at 632 .

29. Jones v. Harris Assocs. L.P., 537 F.3d 728, 729 (7th Cir. 2008) (Posner, J., dissenting from denial of rehearing en banc).

30. Id. at 730 .

31. Jones v. Harris Assocs. L.P., 559 U.S. 335 (2010).

32. 15 U.S.C. $\S 80 \mathrm{a}-35(\mathrm{~b})(5)(2012)$.

33. Id. $\S 80 \mathrm{a}-35(\mathrm{~b})(2012)$.

34. Sec. \& Exch. Comm'n v. Am. Birthright Trust Mgmt. Co., 21 SEC Docket 1241 (Dec. 30, 1980).

35. Section 15(c) of the ICA requires advisers to disclose certain information to funds' boards of directors, and the SEC has occasionally gone after high-fee advisers by alleging that they have failed to disclose these facts. See H. Norman Knickle, The Mutual Fund's Section 15(c) Process: Jones v. Harris, the SEC, and the Fiduciary Duties of Directors, 31 REV. BANKING \& FIN. L. 265 (2011).

36. 15 U.S.C. $\S 80 \mathrm{a}-35(\mathrm{~b})(2012)$. 
ments. ${ }^{37}$ That is, shareholders do not have to demand or show the futility of demanding that the funds' boards of directors pursue the suits.

These features offer tremendous procedural advantages to plaintiffs' lawyers. In essence, they allow a lawyer to bring a suit on behalf of an entire fund without having to bother with either class certification or board demand.

Further, since Section 36(b) suits are neither class actions nor conventional derivative actions, they are not subject to Rules 23 or 23.1 of the Federal Rules of Civil Procedure (FRCP), which regulate class and derivative actions, respectively. ${ }^{38}$ Settlements in Section 36 (b) suits are thus exempt from judicial approval or public disclosure, and most are resolved under FRCP Rule 41(a), which allows parties to voluntarily dismiss a suit with no judicial approval or disclosure as long as both parties agree to the dismissal. ${ }^{39}$

Another procedural quirk is that only the individuals or entities that actually receive a fund's fees may be sued. ${ }^{40}$ As a practical matter, this means that the defendant in a typical Section $36(\mathrm{~b})$ suit is the corporate entity that serves as the fund's adviser, rather than the fund's directors or the officers and directors who work for the adviser entity.

Damages are limited to disgorgement of the portion of fees charged in violation of the fiduciary duty. No damages are recoverable for any period prior to one year before a complaint is filed. ${ }^{41}$

Finally, under Section 36(b)(4), sales loads are expressly exempted from Section 36(b). Sales loads are large, one-time fees charged when an investor first purchases shares. This feature will strike many readers as quite arbitrarywhy exempt sales loads and not other fees?-and we agree. We will discuss the reasons why this distinction is arbitrary in Part II.C.

\section{The Existing Literature}

Mutual fund fee litigation has drawn considerable attention, both critical and supportive. One of the central points of contention has been whether the problem Section $36(\mathrm{~b})$ addresses_-excessive fees-is actually a problem at all. One influential study by Coates and Hubbard ${ }^{42}$ argued that the mutual fund market is largely competitive and suggested that the Gartenberg factors should be altered to reflect the state of the market. ${ }^{43}$ Scholars who are concerned about fees in the mutual fund market are often more favorably disposed to fee litiga-

37. Daily Income Fund, Inc. v. Fox, 464 U.S. 523 (1984).

38. Curtis \& Morley, supra note 3, at 279.

39. Id.

40. 15 U.S.C. $\$ 80 a-35(b)(3)(2012)$.

41. Id.

42. John C. Coates IV \& R. Glenn Hubbard, Competition in the Mutual Fund Industry: Evidence and Implications for Policy, 33 J. CORP. L. 151 (2007); see also R. GLENN HUBBARD ET AL., THE MUTUAL FUND INDUSTRY: COMPETITION AND INVESTOR WELFARE (2010) (stating a similar view).

43. Coates \& Hubbard, supra note 42 , at 202-14. 
tion. ${ }^{44}$ Scholars who view the market as mostly competitive tend to be more skeptical. ${ }^{45}$ Many scholars on both sides have proposed reforms to the Gartenberg factors to make the assessment of excessive fees easier for judges. The Jones case, in particular, sparked a re-examination of fee liability, with few scholars on either side satisfied with the outcome. ${ }^{46}$

Our goal is to broaden the scope of this discussion and consider a different set of questions. Instead of asking whether mutual fund fees are excessive or whether excessive fee liability is justified in the abstract, we ask instead whether the mechanics of fee litigation could be improved. We hope to show that the system is broken in ways that the current literature has failed to highlight and that this is a problem regardless of whether fee liability ought to exist in the first place.

\section{The State of Excessive Fee Litigation}

The current practice of Section 36(b) litigation is, at best, problematic. In a separate study recently published in the Journal of Law, Economics and Organization, we analyzed a collection of nearly all complaints that alleged a breach of Section 36(b) between 2000 and $2009 .{ }^{47}$ We identified ninety-one complaints and matched the names of the targeted mutual funds to a large database containing information about mutual fund fees and performance.

As one might expect, excessive fee litigation is driven almost exclusively by plaintiffs' attorneys rather than by investors. Suits have tended to appear in waves, in which a single lead plaintiffs' firm develops a particular theory of liability and then files a barrage of complaints-occasionally dozens of themalleging breaches under that theory by various mutual advisers. ${ }^{48}$ For example, the Jones case, which was the one that ultimately reached the Supreme Court,

44. See, e.g., James D. Cox \& John W. Payne, Mutual Fund Expense Disclosures: A Behavioral Perspective, 83 WASH. U. L.Q. 907 (2005); John P. Freeman, Stewart L. Brown \& Steve Pomerantz, Mutual Fund Advisory Fees: New Evidence and a Fair Fiduciary Test, 61 OKLA. L. REV. 83 (2008); John P. Freeman \& Stewart L. Brown, Mutual Fund Advisory Fees: The Cost of Conflicts of Interest, 26 J. CORP. L. 609 (2001); Donald C. Langevoort, Private Litigation to Enforce Fiduciary Duties in Mutual Funds: Derivative Suits, Disinterested Directors and the Ideology of Investor Sovereignty, 83 WASH. U. L.Q. 1017 (2005); Ryan Bollman \& Mark Andreu, Note, Jones v. Harris Associates L.P.: The Search for Investor Protection Continues . . , 65 U. MIAMI L. REV. 717 (2011); Samuel S. Kim, Note, Mutual Funds: Solving the Shortcomings of the Independent Director Response to Advisory Self-Dealing Through Use of the Undue Influence Standard, 98 COLUM. L. REV. 474 (1998).

45. See, e.g., John C. Coates IV, The Downside of Judicial Restraint: The (Non-)Effect of Jones v. Harris, 6 DUKE J. Const. L. \& PUB. POL'Y 58 (2010); Coates \& Hubbard, supra note 42; M. Todd Henderson, Justifying Jones, 77 U. CHI. L. REV. 1027 (2010); D. Bruce Johnsen, Myths About Mutual Fund Fees: Economic Insights on Jones v. Harris, 35 J. CORP. L. 561 (2010); Larry E. Ribstein, Federal Misgovernance of Mutual Funds, 2010 CATO SUP. CT. REV. 301.

46. See, e.g., Coates, supra note 45; Jill E. Fisch, Rethinking the Regulation of Securities Intermediaries, 158 U. PA. L. REV. 1961, 1973-75, 1988 (2010); George Steven Swan, The Law and Economics of Mutual Fund Investment-Adviser Fiduciaries: Jones v. Harris Associates L.P., 35 Nova L. REV. 393 (2011).

47. Curtis \& Morley, supra note 3.

48. Id. at $282-83$. 
began as one of twelve complaints brought by two South Carolina law firms in a thirteen-month period between 2004 and $2005 .{ }^{49}$ All of the South Carolina firms' cases alleged simply that the advisers' fees were excessive. ${ }^{50}$ Separately in 2004, Milberg LLP filed a wave of twenty-four complaints alleging that various advisers' fees were too high and that the advisers had illicitly received kickbacks from brokers who received fees to trade on behalf of the funds. ${ }^{51}$ Another cluster of twenty-nine cases, initiated by Baron \& Budd, a Southern plaintiffs' law firm, alleged that various funds had negligently failed to participate in settlement recoveries in shareholder class action suits against companies in the funds' portfolios. ${ }^{52}$

In our recent empirical paper, we ran a variety of statistical tests to understand which funds were likely to end up as targets of Section 36(b) litigation. We found that, compared to funds of similar style, the expense ratios of funds targeted for Section 36(b) suits were not actually higher than those of untargeted funds, except when we controlled for the size of a fund and its "adviser" (or, more precisely, the aggregate size of all of the funds operated by the adviser). ${ }^{53}$ Our core finding was thus that targeted funds were larger and, more importantly, were operated by much larger advisers than untargeted funds. ${ }^{54}$

The driving factor for Section 36(b) litigation thus appears to be the size of the adviser, and not necessarily the fees. While the relationship between fund fees and the likelihood of being targeted in a Section 36(b) suit was statistically significant, the economic magnitude of the relationship was weak. ${ }^{55} \mathrm{~A}$ fund in the highest decile of fees was only $20 \%$ more likely to be targeted than a fund at the median of fees, and the difference in likelihood was not statistically significant. If an adviser with fees in the highest decile wanted to achieve a statistically significant reduction in the probability of being sued, the advisor would have to drop fees down to the third lowest decile, well below the median.

We also found no statistical relationship between fees and how cases were resolved. Fees bore no discernible relationship to the odds that a case would be settled or dismissed by a judge. ${ }^{56}$

Finally, and perhaps most importantly, we found no evidence that fees declined in funds after they had been targeted by Section 36(b) suits. ${ }^{57}$ This is disappointing because the goal of Section $36(\mathrm{~b})$ is not simply to provide compensation, but also to reduce fees going forward.

$\begin{array}{ll}\text { 49. } & I d . \text { at } 282 . \\ 50 . & I d . \\ 51 . & I d . \text { at } 282-83 . \\ 52 . & I d . \text { at } 283 . \\ \text { 53. } & I d \text {. at } 295 . \\ \text { 54. } & I d . \text { at } 228-97 . \\ 55 . & I d . \\ 56 . & I d . \text { at } 298 . \\ 57 . & I d . \text { at } 300-02 .\end{array}$


Note that we were not able to perceive the content of most settlements in Section $36(\mathrm{~b})$ cases. This was because of the unusual settlement process noted above: unlike class actions and derivative suits, in which settlements have to be reviewed and approved by a judge, Section $36(\mathrm{~b})$ cases can be dismissed voluntarily under FRCP Rule 41(a) without any disclosure of settlements. ${ }^{58}$

Excessive fee liability has remained important in the years since the Supreme Court decided Jones. Between 2010 and June 2014, plaintiffs' attorneys have filed fifteen new lawsuits against advisers of open-end funds and one against an adviser of a closed-end fund. ${ }^{59}$ Many of these lawsuits have targeted multiple mutual funds, so the number of affected funds since 2010 is substantially more than fifteen. Thirteen of these recent cases center on the excessiveness of the targeted funds' fees. The remainder focus on forms of misconduct that directly or indirectly affected the amount of fees charged. One recent development is a wave of litigation that premises liability on differences between fees that funds pay directly to their advisers and the fees that the advisers pay to sub-advisers who actually make portfolio investment decisions. ${ }^{60}$ This recent development corroborates our finding that theories of litigation tend to produce waves of similar lawsuits.

\section{Mechanical Flaws in Excessive Fee Liability}

In our empirical study of excessive fee litigation, we were concerned primarily with the relationship between the level of fees on the one hand and the filing and progress of cases on the other. In the course of reviewing litigation records to compile the dataset for that project, however, we became aware of deep mechanical flaws in the design of Section 36(b) and its associated judicial doctrines. These flaws are not necessarily evident in a statistical study of Section 36(b), but they are nevertheless quite striking. The goal of this Article is to

58. See infra Part II.D.

59. Complaint, Hebda v. Davis Selected Advisers, L.P., No. 1:14-cv-4318 (S.D.N.Y. June 16, 2014); Complaint, Goodman v. J.P. Morgan Inv. Mgmt., Inc., No. 2:14-cv-00414 (S.D. Ohio May 5, 2014); Complaint, Kasilag v. Hartford Funds Mgmt. Co., LLC, No. 1:14-cv-01611 (D.N.J. Mar. 12, 2014); Complaint, Clancy v. BlackRock Inv. Mgmt., LLC, No. 3:14-cv-01165 (D.N.J. Feb. 21, 2014); Verified Complaint, Curd v. SEI Invs. Mgmt. Corp., No. 2:13-cv-07219 (E.D. Pa. Dec. 11, 2013); Verified Complaint, McClure v. Russell Inv. Mgmt. Co., No. 1:13-cv-12631 (D. Mass. Oct. 17, 2013); Complaint, Cox v. ING Invs., LLC, No. 1:13-cv-01521 (D. Del. Aug. 30, 2013); Complaint, Am. Chem. \& Equip., Inc. 401(k) Ret. Plan v. Principal Mgmt. Corp., No. 2:13-cv-01601 (N.D. Ala. Aug. 28, 2013); Complaint, Sanford v. AXA Equitable Funds Mgmt. Grp., LLC, No. 3:13-cv-00312 (D.N.J. Apr. 15, 2013); Verified Complaint, Laborers' Local 265 Pension Fund v. iShares Trust, No. 3:13-cv-00046 (M.D. Tenn. Jan. 18, 2013); Complaint and Demand for Jury Trial, Kasilag v. Hartford Inv. Fin. Serv., LLC, No. 2:11-cv-01083 (D.N.J. 2012); Complaint and Jury Demand, Sivolella v. AXA Equitable Life Ins. Co., No. 3:11-cv-04194 (D.N.J. July 21, 2011); Complaint and Demand for Jury Trial, Reso v. Artisan Partners Ltd. P'ship, No. 2:11-cv-00873 (E.D. Wisc. 2011); Class Action Complaint and Jury Demand, Santomenno v. John Hancock Life Ins. Co. (U.S.A.), No. 2:10-cv-01655 (D.N.J. Mar. 31, 2010); Verified Shareholder Derivative Complaint, Cannaday v. Sullivan, No. 2:10-cv-02188 (W.D. Tenn. Mar. 18, 2010).

2013).

60. See, e.g., Complaint, Cox v. ING Invs., LLC, No. 1:13-cv-01521 (D. Del. Aug. 30, 
describe and analyze them. Although some of these flaws arose from deliberate policy choices, most appear to have been the unintended results of Congress' and the courts' misunderstanding of how mutual funds work and how the various parts of the statute and judicial doctrines interact.

\section{A. Failure to Provide General Deterrence}

The first problem is that Section 36(b) does not provide general deterrence. This is primarily because the statute prohibits the award of penalties and only allows for actual damages. Section $36(\mathrm{~b})(3)$ says:

Any award of damages . . . shall be limited to the actual damages resulting from the breach of fiduciary duty and shall in no event exceed the amount of compensation or payment received from such investment company, or the security holders thereof, by such recipient. ${ }^{61}$

This limitation applies to the SEC as well as to investors.

The problem with this limit is that it undermines deterrence. It ensures that advisers have nothing to lose from charging excessive fees. The worst that can happen if an adviser charges excessive fees is that it might have to return the excessive portion of the fees. It is as though the only penalty for theft were that the thief had to return what she stole. So why not try?

Some might argue that this is not actually a problem because Section 36(b) should only provide compensation, not deterrence. This might be true, but it represents a very limited view of what Section 36(b) can accomplish. If indeed Section $36(\mathrm{~b})$ is only supposed to provide compensation and not deterrence, then it is not a plausible solution to the widespread problems of the mutual fund market, since the most expensive funds are rarely, if ever, sued. ${ }^{62}$

Others might argue that Section 36(b) does provide deterrence, but it does so indirectly, in the form of litigation costs. An adviser stands to lose more than just the excessive portion of its fees in a Section $36(\mathrm{~b})$ suit because it has to pay the costs of litigating the suit as well.

This insight has some truth to it, but only some. Litigation costs might be a substitute for more direct penalties, but they are an ineffective and unfair substitute. An adviser can completely eliminate litigation costs by just giving back the excessive portion of the fees without litigating. And litigation costs only loosely correlate with the actual excessiveness of fees: litigation over very high fees is not necessarily more expensive than litigation over moderately high fees. Moreover, in light of the evidence that fee suits target large, moderately priced funds in a scattershot manner, ${ }^{63}$ litigation costs must be borne by the innocent

\footnotetext{
61. 15 U.S.C. $\S 80 \mathrm{a}-35(\mathrm{~b})(3)(2012)$.

62. See infra Part II.G.

63. See infra Part II.E.4.
} 
and the guilty alike. Litigation costs are thus not a form of punishment or deterrence at all; they are simply a tax on the mutual fund business.

\section{B. Recovery Payments to the Wrong Investors}

Another problem is that Section 36(b), by its terms, gives recovery payments to the wrong investors. Section 36(b) sometimes gives recoveries to investors who did not actually pay the fees being recovered and denies recoveries to investors who did pay the fees.

This occurs because of a peculiar detail in how mutual fund shares are bought and sold. Unlike shareholders in ordinary companies, shareholders in mutual funds have the right to "redeem" their shares. Redemption rights allow shareholders to turn over their shares directly to their funds and receive in exchange a cash payout equal to the shares' net asset value or "NAV." The NAV is simply the portion of a fund's total net assets that corresponds to each share. Once a shareholder has redeemed, she is no longer a shareholder of the fund and is no longer entitled to distributions of any revenues received by the fund.

Contrast this with the way that ordinary company shareholders dispose of their shares. Ordinary company shareholders do not redeem their shares from the issuing companies - they sell them instead on markets to other investors.

The redemption process creates a problem for the payment of Section 36(b) recoveries because Section 36 (b) requires recoveries to be paid directly to funds, not to investors. ${ }^{64}$ Hence, any shareholder who redeems just prior to the payment of a recovery receives no portion of it, and any shareholder who purchases just prior to the recovery receives a full share of it. This is true whether or not these shareholders actually paid any portion of the fees being recovered.

A simple example will illustrate. Suppose that in January 2010, an investor purchases stock in a mutual fund with an annual management fee equal to $1 \%$ of the total assets invested. The advisers will charge this fee continuously on a prorated basis by charging the fund each day the portion of the annual fee that is attributable to that day. In other words, every business day the advisers will charge the fund a fee equal to $1 \%$ of the fund's total assets on that day divided by the total number of business days in the year. Investors who have invested in a fund on any given day will thus effectively end up paying the fee for that day, because when the fund makes the payment, the value of each investor's share will automatically decline accordingly. Investors thus pay fees on an ongoing basis in a way that corresponds to the length of time they hold a fund's shares.

Now let us see how this system interacts with the structure of payments in excessive fee cases. Imagine that in January 2011 (one year after our hypothetical first purchase of the shares) another investor sues to recover excessive fees. Since the statute allows plaintiffs to recover fees paid up to one year prior to

64. See 15 U.S.C. $\$ 80 a-35(b)(2012)$. 
the commencement of a suit, the suit will seek recovery of the excessive portion of all fees paid since January 2010, when our investor first placed her money in the fund, as well as any fees paid after the commencement of the suit but before the suit is resolved. Our hypothetical investor who invested in January 2010 will thus have paid all of the fees that are the subject of the suit at the time of its commencement.

Imagine, however, that the case takes several years to resolve, as excessive fee cases often do, ${ }^{65}$ and that no resolution is reached until January 2014, at which point the advisers pay a recovery of several million dollars to the fund. Here is the punch line: if our investor redeems before January 2014, she will receive no portion of the recovery, even though she has invested since 2010 and has paid her share of all of the fees being recovered. Since the recovery must be paid to the fund, rather than directly to the investor, the recovery can benefit only the investors who hold shares at the time the recovery is received. Any investor who has previously redeemed her shares has no way of sharing in the recovery.

Of course, the recovery benefits investors who hold shares at the time the recovery is received by increasing the fund's total assets. But the fund will face no mandate under Section 36(b) to share its recovery with investors who have previously redeemed. Indeed, fund directors would probably breach their ICA fiduciary duties to current shareholders if they shared a recovery with past shareholders.

The mirror image of this situation is also a problem. Investors who did not pay any of the fees being recovered can still receive a recovery by just investing shortly before the recovery is paid to a fund. Imagine, for example, that a sophisticated trader learns of the recovery and invests in the mutual fund one day before the recovery is received. This sophisticated trader will have paid none of the fees being recovered-she did not hold shares at the time the fees were charged-but she will nevertheless share in the recovery on the same terms as every other shareholder in the fund. If the trader invests enough money to comprise half of the mutual fund's total assets, for example, she would be entitled to half of the total recovery. In such a manner, a shrewd trader might effectively steal a Section $36(\mathrm{~b})$ recovery.

Ordinary companies do not face this kind of problem. Ordinary company shareholders do not redeem; they buy and sell in markets. Ordinary company share prices thus reflect expected values since expected value is what investors are willing to pay in the markets for shares. This means that if an ordinary company expects to receive a large recovery in a derivative lawsuit, the ordinary company's share prices will increase immediately in expectation of the

65. The average time to resolution of the cases that had been resolved in our earlier study was about two years. The average time to resolution for the cases that had been unresolved at the time we compiled our data was much longer. 
recovery. Any shareholder who sells will thus receive the expected value of the recovery, and any shareholder who buys will have to pay that expected value.

Mutual funds' share prices do not change in this way. The price of a mutual fund's shares is always exactly equal to its net asset value. The net asset value is simply the sum total of the value of the securities in the portfolio at any given moment minus the fund's liabilities. In other words, mutual funds' shares are priced at liquidation value, not expected value. Mutual fund share prices thus cannot adjust automatically to reflect expected litigation recoveries in the future. This is part of a more general problem in mutual fund pricing that is well known in financial economics and has been reflected in parts of the Internal Revenue Code. ${ }^{66}$

In practice, it is difficult to say precisely how big of a problem this mismatch between recoveries and investors has been. But if Section 36(b) ever actually functions as its advocates wish and achieves large recoveries, this will become a serious problem indeed.

\section{Inconsistent Treatment of Sales Loads and Other Types of Fees}

Another problem with Section $36(\mathrm{~b})$ is that it treats similar types of fees differently. Section 36(b)(4) expressly exempts sales loads from Section 36(b)'s fiduciary duty. ${ }^{67}$ The section says, "[T]his subsection shall not apply . . to sales loads for the acquisition of any security issued by a registered investment company." $" 68$

Sales loads are one-time fees that investors pay when they first purchase shares in mutual funds. Advisers commonly use the revenue derived from these fees to pay for sales and distribution-related expenses, such as advertising and commissions to brokers and financial advisers who sell the shares. ${ }^{69}$ Sales loads are different from various other types of fees, including so-called "management fees," which advisers charge continuously at an annual rate to pay for ongoing expenses such as portfolio management.

The basic problem is that sales loads and other types of fees are substitutes for one another. It is therefore impossible to evaluate management fees and other types of fees without also evaluating sales loads. Sales loads and other types of fees can be used interchangeably to alter the timing of fees, even while keeping the total net present value of fees the same. Sales loads shift the fees up front, and annual fees shift them later. The difference between sales

66. Morley \& Curtis, supra note 8, at 103 (explaining the mechanics of mutual fund share pricing); Michael J. Barclay, Neil D. Pearson \& Michael S. Weisbach, Open-End Mutual Funds and Capital-Gains Taxes, 49 J. FIN. ECON. 3 (1998) (identifying the so-called "tax overhang" problem that afflicts mutual funds because of the mismatch between expected tax liabilities and current NAV).

67. 15 U.S.C. $\$ 80 \mathrm{a}-35(\mathrm{~b})(4)(2012)$.

68. Id.

69. See generally Brad M. Barber et al,, Out of Sight, Out of Mind: The Effects of Expenses on Mutual Fund Flows, 78 J. Bus. 2095 (2005). 
loads and other fees is therefore more about timing than amount. Hence, it is impossible to consider one type of fee in isolation from others.

For example, long-term investors might choose to pay high sales loads up front in exchange for lower annual management fees in the future. And shortterm investors might choose the opposite, electing to pay high annual fees in exchange for low sales loads up front. Mutual funds commonly structure their pricing accordingly. A single fund may offer different share classes with different combinations of sales loads and annual fees in order to appeal to potential investors' differing time horizons. ${ }^{70}$

This point is established in financial economics. In empirical studies of mutual fund fees, economists recognize that different types of fees are fungible, so they use various strategies to deal with the problem. One such strategy, for example, is to convert sales loads into the equivalent of annual fees by amortizing the sales loads. Economists add $1 / 5$ or $1 / 7$ of a fund's total sales load to its annual management fees in order to arrive at a uniform measure of a fund's "annual" fees. ${ }^{71}$ The logic is that a median investor might typically hold shares for five or seven years, and so if we want to assess the investor's true annual cost, we must spread the one-time sales load across each year of investment.

Sales loads are especially fungible with a kind of fee called a " $12 b-1$ " fee. Up until the 1970s, most of mutual fund advisers' revenue came from sales loads. ${ }^{72}$ But in 1980 , the SEC began a slow shift away from sales loads by adopting Investment Company Act Rule $12 \mathrm{~b}-1 .{ }^{73}$ Rule $12 \mathrm{~b}-1$ allows advisers to charge sales fees every year, not just up front on a one-time basis. An adviser can use the revenue from these annual fees to pay for the same types of distribution expenses that sales loads traditionally covered, including advertising and the commissions that the adviser pays to brokers who sell the funds' shares. These 12b-1 fees are controversial, but they have become widespread and have largely replaced sales loads. ${ }^{74}$

Since Rule 12b-1 fees are designed to cover the same kinds of distribution-related adviser expenses that sales loads cover, Rule $12 \mathrm{~b}-1$ fees are widely

70. Xiaohui Gao \& Miles Livingston, The Components of Mutual Fund Fees, 17 FIN. MARKETS, INSTITUTIONS \& INSTRUMENTS 197, 202 (2008) (discussing the typical allocation of different types of fees across a single fund's different share classes); Vikram Nanda et al., The ABCs of Mutual Funds: On the Introduction of Multiple Share Classes, 18 J. FIN. INTERMEDIATION 329, 330 (2009) (discussing the same). Multiple share classes are permitted by Investment Company Act Rule 18f-3. 17 C.F.R. $\S 270.18 f-3(2013)$.

71. See Erik R. Sirri \& Peter Tufano, Costly Search and Mutual Fund Flows, 53 J. FIN. 1589,1593 (1998) (amortizing sales loads by dividing them by 7 and adding them to annual fees).

72. SEC. \& EXCH. COMM'N, supra note 20, at 20-21.

73. Bearing of Distribution Expenses by Mutual Funds, 45 Fed. Reg. 73,898 (Nov. 7, 1980) (to be codified at 17 C.F.R. pt. 239, 270, 274).

74. Barber et al., supra note 69 (observing that the number of funds charging front-end loads has declined dramatically in recent years); Daniel Bergstresser, John M. R. Chalmers \& Peter Tufano, Assessing the Costs and Benefits of Brokers in the Mutual Fund Industry, 22 REV. FIN. STUD. $4129,4129-30$ (2009) (observing that in 2002, 12b-1 fees totaled $\$ 8.8$ billion in the mutual fund industry, or $23 \%$ of total adviser revenue). 
understood to be direct substitutes for sales loads. The Investment Company Institute, the primary trade organization for mutual fund advisers, states it bluntly: "[f]or most of their history, 12b-1 fees have been widely used on a continuing basis as a substitute for sales loads."75

The only apparent reason for the disparate treatment of sales loads and $12 b-1$ fees in Section 36(b) is that 12b-1 fees did not exist until 1980, ten years after Congress adopted Section 36(b). In other words, Congress probably just neglected to update section 36 (b) to reflect the existence of $12 \mathrm{~b}-1$ fees.

There is no longer any persuasive rationale for the unique treatment of sales loads. When Congress first enacted Section 36(b) in 1970, its apparent logic was that sales loads were subject to separate regulation by the predecessor organization to what is now known as the Financial Industry Regulatory Authority, or FINRA. FINRA is a private regulatory authority for the securities industry. ${ }^{76}$ Section $22(\mathrm{~b})(1)$ of the ICA, which Congress added at the same time as Section 36(b), empowered FINRA to regulate sales loads. ${ }^{77}$ FINRA then enacted a set of rules that impose hard caps on sales loads. These rules are still in force today. ${ }^{78}$

The interesting thing to note is that even FINRA itself recognizes the fungibility of sales loads and $12 \mathrm{~b}-1$ fees. FINRA's sales load regulation adjusts the caps on sales loads up or down based on whether a particular fund charges $12 \mathrm{~b}$ 1 fees. ${ }^{79}$ Funds with $12 \mathrm{~b}-1$ fees must charge lower sales loads than funds without $12 \mathrm{~b}-1$ fees. FINRA also prohibits funds from claiming that they do not charge load fees if they charge $12 \mathrm{~b}-1$ fees in excess of a small amount. ${ }^{80}$ The logic, in essence, is that $12 \mathrm{~b}-1$ fees are just load fees by another name, so any attempt to regulate load fees must also take $12 \mathrm{~b}-1$ fees into account.

75. 12b-1 Resource Center: Introduction, INV. CO. INST., http://www.ici.org /rule12bl fees (last visited Feb. 13, 2014).

76. Prior to the Investment Company Amendments Act of 1970 , which included section 36(b), FINRA had regulated sales loads under the authority of the Investment Company Act's original $\S 22$ (b). Investment Company Act of 1940, ch. 686, § 22(b), 54 Stat. 789, 823-25; In the Matter of a Proposed Amendment to the Rules of Fair Practice of National Association of Securities Dealers, Inc., Exchange Act Release No. 2866, Investment Company Act Release No. 118, 1941 WL 37273 (April 12, 1941) (implementing FINRA's authority over sales loads by adopting Section 26(d), Article III of the Rules of Fair Practice of the NASD, which prohibited members from participating in an offering that includes "gross selling commission or load which is unfair."). The early drafts of the legislation that eventually led to the enactment of Section $36(\mathrm{~b})$ would have placed a direct $5 \%$ cap on sales loads. S. 1659, 90th Cong. $\S 12$ (c)(1) (1967). The industry opposed this, however, and ultimately obtained the current version of the statute. Hearing on S. 1659 Before the S. Comm. on Banking \& Currency, 90th Cong. 46, 174, 215, 561, 624 (1967).

77. Investment Company Amendments Act of 1970, Pub, L. No. 91-547, sec. 12, § 22, 84 Stat. $1413,1422-23$.

78. FIN. INDUS. REG. AUTH., FINRA MANUAL 17,275-99 (2009), http:// finra.complinet.com/en/display/display_main.html?rbid=2403\&element_id=3691 (NASD Rule 2830(d)).

79. Compare id. at 17,297 (NASD Rule 2830 (d)(1) regulating sales loads in mutual funds without $12 \mathrm{~b}-1$ fees), with id. at 17,297-98 (NASD Rule $2830(\mathrm{~d})(2)$ regulating sales loads in mutual funds with $12 \mathrm{~b}-1$ fees).

80. Id. at 17,298-99 (NASD Rule 2830(d)(4)). 
There is no reason why sales loads could not be subject to both FINRA regulation and Section 36(b) regulation. Rule 12b-1 fees are already subject to both types of regulation, and load fees could easily be too. And even if sales loads ought to be exempt from Section 36(b), Section 36(b) should at least adjust its assessment of other fees to somehow take sales loads into account.

\section{Awkward Settlement Process}

Section 36(b)'s statutory language and judicial precedent have also created an awkward and highly unusual settlement process. While plaintiffs can sue on behalf of all of a fund's shareholders, they cannot settle on behalf of all of the fund's shareholders. Because Section 36(b) suits are not class actions and not technically derivative actions, there is no mechanism in the Federal Rules of Civil Procedure that allows a named plaintiff to bind unnamed shareholders to a settlement. Defendants who settle with one set of plaintiffs must simply cross their fingers and hope that they do not get sued by another set of plaintiffs for the exact same claims covering the exact same shareholders for the exact same periods of time.

The problem arises from Section 36(b)'s odd placement in a kind of procedural no-man's-land: Section 36(b) suits are not exactly individual actions, but they are not exactly class actions or derivative actions either. They are not individual actions because recoveries go to funds rather than investors. They are not class actions because they can be litigated by individual investors acting alone without class certification and also because any recoveries must go to the funds rather than to a class of investor plaintiffs. Section $36(\mathrm{~b})$ suits are also not conventional derivative actions because they can only be initiated by investors or the SEC, not by the funds themselves. The Supreme Court has thus exempted Section 36(b) suits from FRCP Rule 23, which governs class actions, and 23.1, which governs derivative actions. ${ }^{81}$ The Court's logic was that Rule 23.1 only applies to suits "which may properly be asserted" by a corporation acting on its own behalf, but that Section 36(b) may not be asserted by a fund on its own behalf. 82

Because Section 36(b) suits are not subject to Rules 23 or 23.1, there is no mechanism that can bind unnamed plaintiffs to settlements. Ordinarily, settlements in class action and derivative suits can bind unnamed plaintiffs because Rules 23 and 23.1 establish procedures to ensure the settlements' faimess. ${ }^{83}$ Settlements must be reviewed and approved by judges, so the settlements can bind every shareholder or every plaintiff who does not expressly opt out. Section 36(b) suits, by contrast, can be settled without judicial review. Almost all settlements in Section 36(b) suits occur under FRCP Rule 41(a), which allows

81. Daily Income Fund, Inc. v. Fox, 464 U.S. 523 (1984).

82. Id. at $527-30$.

83. FED. R. CIV. P. 23(e). 
plaintiffs to execute settlements by just filing a one-page motion to dismiss with both parties' signatures at the bottom. ${ }^{84}$ Because the settlements bind only the plaintiffs, the motion does not have to obtain judicial approval and does not even have to disclose whether the plaintiff received a settlement payment.

This creates a kind of asymmetry: plaintiffs can initiate suits that seek recoveries on behalf of entire funds but can only settle suits on behalf of themselves. Although an adjudicated verdict in a Section 36(b) case can bind all of the shareholders in a fund, a settlement cannot. Hence, when defendants settle, they gain no assurance that future plaintiffs will not come along and make the exact same claims for the exact same shareholders and time periods. Defendants can only cross their fingers and hope.

We speculate that the reason Congress and the Supreme Court adopted this strange system was that they were trying to thread a needle. They wanted to allow funds to receive recoveries directly but did not want to allow the funds' boards of directors to take control of the lawsuits through the conventional FRCP 23.1 "demand" process. The demand process forces plaintiffs in derivative suits either to request that a company's board pursue the suit on its own or to show the futility of making such a request. ${ }^{85}$ Congress thought it was imperative that mutual fund boards not be able to hassle plaintiffs in this way because mutual fund boards are never independent of their advisers. That was the whole point of Section 36(b).

There is, however, a simpler way around the board control problem: Section 36(b) could give recoveries to investors rather than to funds. Giving recoveries directly to investors would solve the settlement problem by making the suits into class actions governable by Rule 23 . It would also solve the mismatch between recoveries and investors noted above. ${ }^{86}$ It is unclear why exactly Congress wanted to prevent recoveries from going straight to investors, and there does not seem to be any good reason why they should not. There are no practical obstacles to tracking down mutual fund shareholders because mutual fund shareholders use class action lawsuits all the time in other types of lawsuits. ${ }^{87}$

Perhaps the only reason that this clunky settlement procedure has survived for so long is that other mechanical problems in Section 36(b) have mitigated its seriousness. As we will see below, the incentives to bring Section 36(b) suits are extremely weak, and this has reduced the incentives for multiple plaintiffs

84. Curtis \& Morley, supra note 3, at 297-98. For an example of a one-page Rule 41(a) motion in a Section 36(b) case, see Notice of Dismissal with Prejudice, Sable v. Janus Capital Management, No. 1:07-cv-00165 (D. Colo. May 1, 2007).

85. FRCP 23.1(b)(3) requires plaintiffs to "state with particularity: (A) any effort by the plaintiff to obtain the desired action from the directors or comparable authority and, if necessary, from the shareholders or members; and (B) the reasons for not obtaining the action or not making the effort." FED. R. CIV. P. 23.1(b)(3).

86. See supra Part II.B.

87. The lawsuits that grew out of the market-timing and late-trading scandals of 2004 and 2005, for example, generally involved direct claims on behalf of shareholders. See, e.g., Janus Capital Grp. v. First Derivative Traders, 131 S. Ct. 2296 (2010). 
to try to sue on the same claims. The weakness of incentives does not truly fix the settlement problem, however-it just masks it. If Section 36(b)'s scheme of incentives is ever fixed to make excessive fee suits more attractive-as it must be if Section 36(b) is ever to have any real impact-then the settlement process will very quickly be exposed as a serious problem.

\section{E. Exposure of Low-Fee Advisers to Litigation Risk}

Section 36(b) also does a poor job of insulating low-fee advisers from litigation risk. Advisers face substantial litigation risk and burdensome litigation costs even when they charge fees well below market norms.

This matters for two reasons. First, it is unfair to low-fee advisers. Second, and perhaps more importantly, it undermines deterrence. If even low-fee advisers incur significant costs under Section 36(b), then why should advisers lower their fees? Section $36(\mathrm{~b})$ can only encourage lower fees if it meaningfully differentiates between high- and low-fee funds.

The problems come primarily from judicial doctrine. Gartenberg heldexpressly and emphatically-that even advisers who charge fees below prevailing market rates can potentially be liable. This has made it difficult for low-fee advisers to win on motions to dismiss and motions for summary judgment. ${ }^{88}$

\section{The Scrutiny of Low-Fee Advisers}

When the Second Circuit decided Gartenberg in 1982, most courts remained uncertain about what exactly an "excessive" fee was and even about whether excessiveness was actually the issue that Section 36(b) sought to address. Since Section 36(b) itself mentioned only a vague "fiduciary duty," Gartenberg had to grapple with basic questions about whether excessiveness would matter and what it would mean. The district court in Gartenberg had resolved these uncertainties by holding that the principal factor a court should consider was how a fund's fees compared to those of its peers (i.e., other funds that provided similar services). ${ }^{89} \mathrm{~A}$ court would assess the fees of a money market mutual fund, for example, by comparing its fees to those of other money market mutual funds.

This was an obvious and common sense approach, but on appeal the Second Circuit expressly rejected it. After considering the district court's comparison-focused standard, the Second Circuit held that "[r]eliance on prevailing industry advisory fees will not satisfy $\S 36(\mathrm{~b}) . " 90$ In other words, looking at similar funds was not enough.

\footnotetext{
88. Gartenberg v. Merrill Lynch Asset Mgmt., Inc., 694 F.2d 923, 929 (2d Cir. 1982).

89. Id.

90. Id.
} 
The reason, according to Gartenberg, was that market competition was failing across the entire mutual fund industry. A court could not just look at other funds because all of those other funds were tainted as well. The court explained,

\begin{abstract}
We disagree with the district court's suggestions that the principal factor to be considered in evaluating a fee's faimess is the price charged by other similar advisers to funds managed by them, that the "price charged by advisers to those funds establishes the free and open market level for fiduciary compensation," that the "market price... serves as a standard to test the fairness of the investment advisory fee," and that a fee is fair if it "is in harmony with the broad and prevailing market choice available to the investor[.]" ... Reliance on prevailing industry advisory fees will not satisfy $\S 36(b) .^{91}$
\end{abstract}

This was a profound-and profoundly troubling-move. The Gartenberg court claimed, in effect, that an entire industry was a giant scam.

To make this move, the court relied on the observation that "investment advisers seldom, if ever, compete with each other for advisory contracts with mutual funds." 92 The court was referring to the fact that mutual funds are always established and operated by external advisers with separate corporate existences and separate owners. One enduring feature of this separation is that advisers and their funds are not fully independent of each other. Although the ICA tries to encourage mutual funds to be somewhat independent from their advisers, as a practical matter the funds almost never fire their advisers and are almost completely dominated by them. ${ }^{93}$

We do not find this troubling. As we have explained elsewhere, the reason funds never fire their advisers is that investors can simply redeem their shares. ${ }^{94}$ Investors never pressure the funds' boards of directors to fire their advisers because any investors who are unhappy can fire their advisers unilaterally by just withdrawing their money. This observation holds even if some mutual fund investors fail to redeem, perhaps because they are not paying attention or lack financial sophistication. These investors will not vote for the very same reasons they do not withdraw. If withdrawing money is hard, running a proxy campaign is vastly harder. Hence, fund directors have essentially no reason to fire their advisers.

This is not the case with ordinary companies. In ordinary companies, investors cannot redeem; they can only sell. And when they sell, their assets remain stuck inside the company. Hence, the only way an ordinary company's investors can stop a company's CEO from mismanaging their money is to ask the board to fire her.

91. Id. (emphasis added) (citations omitted).

92. Id. (internal quotations omitted).

93. Morley, supra note 9.

94. Morley \& Curtis, supra note 8. 
That investors do not vote is a basic truth about mutual funds, and we do not think it should be controversial. The Gartenberg court, however, was making its decision at a time before this basic truth was discovered. Gartenberg thus found the tight linkage between funds and advisers very troubling. It argued, " $[\mathrm{T}]$ he existence in most cases of an unseverable relationship between the adviser-manager and the fund it services tends to weaken the weight to be given to rates charged by advisers of other similar funds." 95

Gartenberg's emphasis on the linkage between funds and advisers was typical of the thinking at the time. ${ }^{96}$ Very few modern commentators, however, would agree with this emphasis on the linkage between funds and their advisers. ${ }^{97}$ Nowadays, almost everyone agrees that the relevant question in assessing competition is not whether funds fire their advisers, but whether investors do. ${ }^{98}$ Because investors in mutual funds can withdraw their money, they can essentially fire their managers themselves. So the question is whether they do this. If investors actively search for low-fee mutual funds and redeem their shares when fees get out of line, then it does not matter how actively advisers compete for the contracts to manage mutual funds because advisers' competition to attract investors will be enough. Of course, reasonable minds can and do disagree over just how actively investors search for competitive funds. But almost everyone acknowledges that investors - and not funds - are the appropriate objects of focus.

Moreover, almost every commentator now agrees that, even if some portion of the mutual fund market is not competitive, a large portion of it clearly is. This has been most clearly established by the pioneering work of John Coates and Glenn Hubbard. ${ }^{99}$ Although some observers disagree with Coates and Hubbard on the precise extent of competition, ${ }^{100}$ it seems that there is now a wide consensus that large portions of the mutual fund market are highly competitive. ${ }^{101}$ There is thus no longer any basis for Gartenberg's universal skepticism of all mutual funds.

95. Gartenberg, 694 F.2d at 929.

96. The Gartenberg court actually derived its emphasis on the fund-adviser relationship from a 1966 report by the SEC, which lamented the connection between funds and advisers and argued that funds needed greater independence. That same report also provided the impetus for Congress's initial adoption of section 36(b). SEC. \& EXCH. COMM'N, supra note 20.

44.

97. There are only a handful of exceptions. See, e.g., Freeman \& Brown, supra note

98. For the best examples of this view, see Coates \& Hubbard, supra note 42; HUBBARD ET AL., supra note 42.

99. Coates \& Hubbard, supra note 42; HUBBARD ET AL., supra note 42.

100. E.g., Brief for Robert Litan et al. as Amici Curiae Supporting Petitioners, Jones v. Harris Assocs. L.P., 559 U.S. 335 (2010) (No. 08-586); Birdthistle, supra note 15.

101. For example, index funds occupy an increasing segment of the mutual fund market place and compete aggressively on fees. INV. Co. INST., 2014 INVESTMENT COMPANY FACT BooK fig. 2.12 and accompanying text, http://www.icifactbook.org/fb_ch2.html\#index. See also Coates \& Hubbard, supra note 42; M. Todd Henderson, Justifying Jones, 77 U. CHI. L. REV. 1027, 1035 (2010). The claim that a substantial portion of the mutual fund market competes on price is distinct from the claim that an average-cost actively managed fund is a good investment choice compared to a low cost 
The end result of Gartenberg's universal skepticism of all funds, however, was that even comparatively low-fee funds became subject to scrutiny. If the entire industry is a scandal, as Gartenberg suggests, then even the low-fee funds are tainted. Gartenberg's reasoning in this regard and its enjoinder to avoid reliance on prevailing market fees was reaffirmed by the Supreme Court in Jones. ${ }^{102}$

\section{The Difficulty of Summary Judgment}

The practical problem this de-emphasis on comparative fees creates is that low-fee advisers now have an unduly difficult time winning on motions to dismiss and motions for summary judgment. In the years after Gartenberg, the circuit courts dealt with Gartenberg's prohibition on fee comparisons by applying instead a six-factor test. Since Gartenberg insisted that even low-fee advisers might be overcharging, the net result is that now even low-fee advisers must run the full gauntlet of this complicated and ambiguous test. This is what makes summary judgment and dismissal unduly hard to obtain for low-fee advisers.

The six factors are as follows:

(1) the nature and quality of services provided to fund shareholders; (2) the profitability of the fund to the adviser-manager; (3) fall-out benefits; (4) economies of scale; (5) comparative fee structures; and (6) the independence and conscientiousness of the trustees. ${ }^{103}$

These factors are so extensive and so ambiguous in scope that they create substantial obstacles to disposing of claims on the pleadings, even when a fund has relatively low fees.

The profitability of the fund's adviser, for example, involves a complicated inquiry into what portion of an adviser's total costs is attributable to the operation of a particular fund. Since most advisers simultaneously operate dozens or even hundreds of funds and apply many of the same resources to the management of all of those funds, it is very difficult to separate out the cost of operating any particular fund so that its profitability can be determined. ${ }^{104}$

Although low-fee funds can expect to score well on these factors at trial, they must wait for trial to do so because it is difficult to reach a resolution prior to trial. Jones itself illustrated the point. The district court granted summary

index fund. While the debate is beyond the scope of this Article, it is possible that actively managed funds compete on price and nevertheless represent an inferior alternative to index funds or other low cost options.

102. Jones v. Harris Assocs. L.P., 559 U.S. 335 (2010).

103. Krinsk v. Fund Asset Mgmt., Inc., 875 F.2d 404, 409 (2d Cir. 1989).

104. For an excellent analysis of these difficulties, see Sean M. Murphy \& James G. Cavoli, Fund Profitability in Mutual Fund Fee Litigation, 45 REV. SEC. \& CoMMODITIES REG. 81 (2012). 
judgment for the defendants. On appeal to the Seventh Circuit, Judge Easterbrook observed that there was no genuine dispute about the defendant's relative fees. "It is undisputed," he observed, "that these fees are roughly the same (in both level and breakpoints) as those that other funds of similar size and investment goals pay their advisers, and that the fee structure is lawful under the Investment Advisers Act." ${ }^{105}$ Hence, Judge Easterbrook affirmed the grant of summary judgment. The Supreme Court, however, reversed because it applied the Gartenberg standard. ${ }^{106}$ And the Gartenberg standard insists that even lowand moderate-fee advisers must run the full gauntlet of the six-factor test.

\section{The Absence of Screening Prior to Summary Judgment}

A related problem is that Section 36(b) does very little to screen excessive fee cases prior to summary judgment. Unlike cases involving allegations of fraud, excessive fee cases do not invoke special statutorily heightened pleading standards. The most important source of heightened pleading standards in securities litigation, the Private Securities Litigation Reform Act of 1995 (PSLRA), does not apply, because its standards are triggered only by suits brought under the Securities Exchange Act of 1934, not the ICA. ${ }^{107}$ And even if the PSLRA did apply, it would have no meaningful impact because the heightened requirements apply to pleas of fraud, while excessive fee suits do not require allegations of fraud. Federal Rule of Civil Procedure 9(b), which imposes heightened pleading requirements for allegations of fraud, also does not apply for similar reasons. ${ }^{108}$

The fact that excessive fee suits are neither class actions nor derivative actions further loosens the screening, because plaintiffs do not have to certify a class or prove the futility of board demand. Of course, neither class certification nor demand futility are designed to screen cases on the merits, but they have the practical effect of limiting some of the lowest expected-value suits in other contexts. In Section 36(b), plaintiffs can wield claims on behalf of an entire fund without expending any significant effort of their own.

\section{The Empirical Evidence}

In this Subsection we present some results from our comprehensive empirical analysis of Section 36(b) litigation in order to provide some quantitative context for the structural problems above. The data below were collected by searching for all Section 36(b) cases brought between 2000 and 2009 and matching the funds named in each lawsuit against a database of mutual fund fee

105. Jones v. Harris Assocs. L.P., 527 F.3d 627, 631 (7th Cir. 2008).

106. See Jones v. Harris Assocs. L.P., 559 U.S. 335 (2010).

107. 15 U.S.C. $\S 78 u-4(b)(2)(A)$ (2012) (requiring heightened pleading for private actions arising "under this chapter").

108. FED. R. CIV. P. 9(b). 
and performance information. ${ }^{109}$ The consequences of exposing low-fee advisers to litigation are not surprising: a large portion of excessive fee suits target low-fee advisers, as Figure 1 illustrates.

Figure 1: Comparative Plot of Targeted and Untargeted Funds

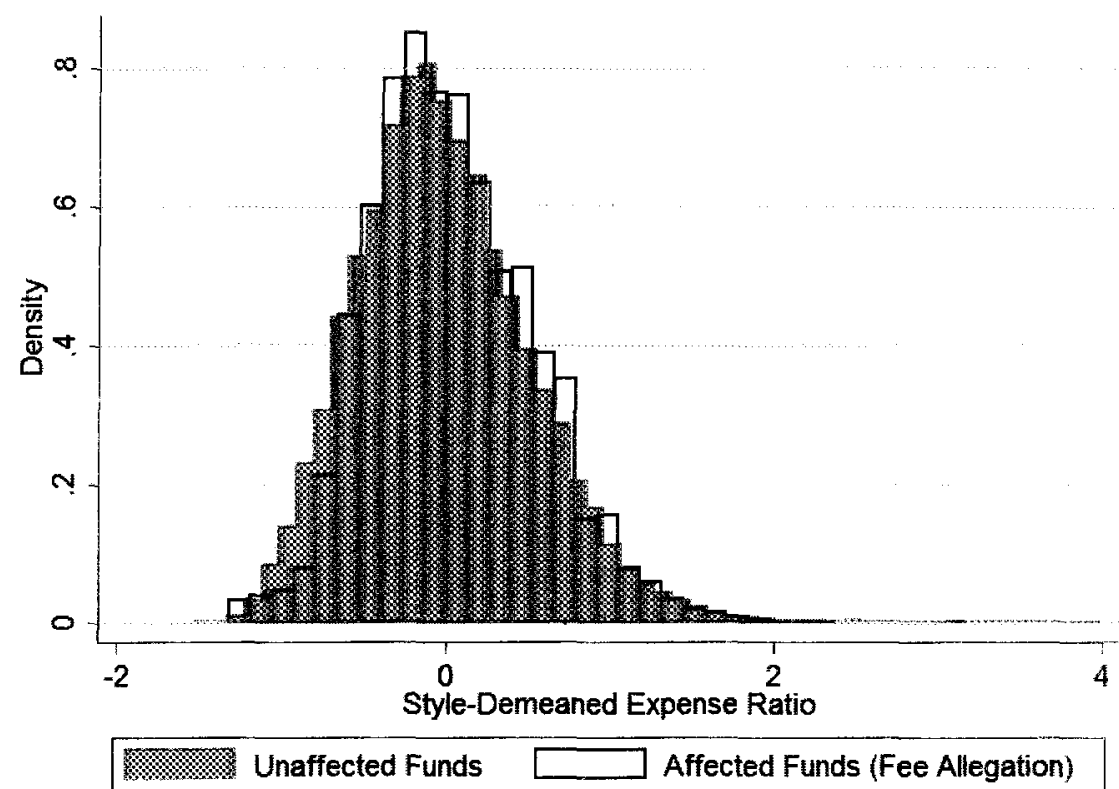

Figure 1 depicts a density plot showing the fees of funds that were and were not targeted for excessive fee suits. ${ }^{110}$ The grey bars represent fees in funds targeted by lawsuits, and the clear bars in black outline represent fees in funds that were not targeted. What is immediately evident is that the two histograms trace very similar curves. That is, the fees of the targeted funds and the fees of the untargeted funds are almost identical.

Figure 2 paints a similar picture. ${ }^{111}$ It shows how excessive fee suits were distributed across funds based on their fees. It divides funds into ten deciles based on their style-adjusted fees and shows the number of suits that affected funds in each decile. There is a gradual upward slope to the graph, suggesting a positive relationship between fees and the probability of being targeted for an excessive fee suit. But the slope does not angle as sharply upward as one might

109. The data and methodology are fully described in Curtis \& Morley, supra note 3.

110. The fees for each fund are calculated relative to the mean among other funds with the same investing styles between 2000 and 2010 . The figure observes all open-end mutual funds on a quarterly basis. Data on fees throughout this Article come from the Center for Research in Securities Prices' Survivor-Bias Free Mutual Fund Database. See id.

111. Id. at 40 . 
expect given the language of Gartenberg, and, in particular, it does not spike at the high end. And perhaps more important than the slope is simply the height of the bars. Even if there are more funds being targeted at the high end of the fee distribution than at the low end, the fact remains that a distressingly large number of funds are still being targeted at the low end.

Figure 2: Suit Incidence by Fee Decile

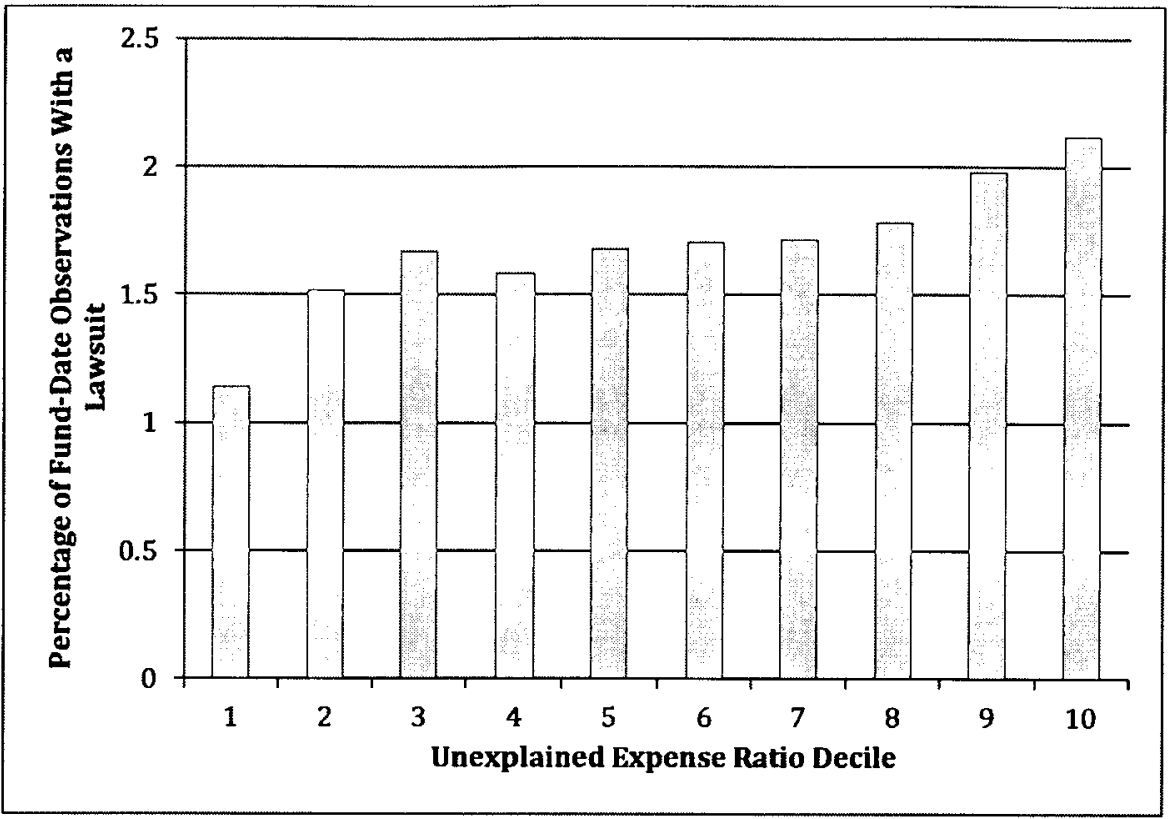

Table 1 summarizes the procedural progress of Section $36(\mathrm{~b})$ cases. The Table includes almost every Section 36(b) case filed between 2000 and February 2014-including those filed since Jones-whose procedural status was clearly discernible and shows the stage at which all of the closed cases were resolved. ${ }^{112}$ Cases that were unresolved as of late February 2014 are included in the category "unresolved." Cases listed as "voluntary resolutions" were those resolved by voluntary plaintiff dismissals under FRCP Rule 41(a). Unfortunately, because Rule 41(a) does not require disclosure or judicial approval of settlements, we cannot tell whether voluntary dismissals under Rule 41(a) involved settlements or mere abandonment of claims by plaintiffs.

112. The Table excludes cases that alleged market-timing or late-trading between 2003 and 2005 as well as cases that involved closed-end funds. The Table defines a "case" to count each consolidated suit as a single suit. The case treats district court resolutions as final resolutions in cases in which appeals of district court decisions are pending as of late February 2014. The Table presents only the progress of Section 36(b) claims and ignores the progress of other claims, such as Rule 10b-5 claims, that may have been included in the suits. 
Table 1 does not tell a clear story, mostly because it is impossible to know what optimal resolutions would look like. Obviously, some cases are surviving motions to dismiss, but it is hard to say whether there are too many or too few. Obviously some cases ought to make it past motions to dismiss, even in our view, but no one can say precisely how many. We have written a little about this topic in our empirical study, and we have found no discernible relationship between fees and resolutions. ${ }^{113}$ It is also impossible to say whether settlements prior to dismissal are good or bad. Nevertheless, Table 1 does clearly illustrate that Section 36(b) cases are not routinely dismissed.

Table 1: Procedural Progress of Section 36(b) Cases Between 2000 and

February 2014

\begin{tabular}{|c|c|}
\hline & Number \\
\hline \multicolumn{2}{|l|}{ Resolved cases } \\
\hline $\begin{array}{l}\text { Voluntary resolution prior to ruling on motion to dismiss } \\
\text { Dismissed }\end{array}$ & $\begin{array}{l}38 \\
37\end{array}$ \\
\hline $\begin{array}{l}\text { Voluntary resolution after denial of motion to dismiss } \\
\text { Summary judgment for defendants } \\
\text { Trial }\end{array}$ & $\begin{array}{c}16 \\
5 \\
1\end{array}$ \\
\hline Unresolved cases & 6 \\
\hline
\end{tabular}

We should also note that Section 36(b) cases often require significant time and effort from defendants. Among all the cases that were filed since 2000 and resolved by the time Jones was decided, the average length to resolution was 959 days, or 2.6 years. ${ }^{114}$

\section{Objections}

The obvious objection to all of these worries about the plight of low-fee advisers is that maybe Gartenberg was right: perhaps competition really is a problem across the entire mutual fund industry. Maybe even low-fee advisers are overcharging their clients. While Gartenberg's original concern about how boards refuse to fire their advisers is clearly irrelevant, there are other, more serious reasons for concern about the health of mutual fund market competition. In particular, there is now a large and growing body of evidence that many mutual fund investors do not understand the central importance of fees in determining net returns. ${ }^{115}$ And the mutual fund industry continues to market active-

113. Curtis \& Morley, supra note 3, at 297-300.

114. This number is based on the same data as Table 1 .

115. James J. Choi et al., Why Does the Law of One Price Fail? An Experiment on Index Mutual Funds, 23 REV. FIN. STUD. 1405 (2010) (showing in a field experiment that retirement plan participants prioritize past returns over fees in selecting a plan); Molly Mercer et al., Worthless Warnings? Testing the Effectiveness of Disclaimers in Mutual Fund Advertisements, 7 J. EMPIRICAL 
ly managed funds despite their demonstrated incapacity to outperform lowercost index funds. ${ }^{116}$

We take all of these concerns very seriously, but we do not believe that they warrant exposing low-fee funds to litigation, for several reasons. First, as we explained above, even if some of the market is not competitive, most of it, or at least a sizable portion of it, clearly is. It is unfair to punish advisers who charge genuinely competitive fees. Second, punishing low-fee advisers is counterproductive because it reduces deterrence. If even low-fee advisers get punished, then why should advisers lower their fees? Finally, if indeed the entire mutual fund market were uncompetitive, then Section 36(b) would be a hopelessly inadequate solution. If the entire market were such a mess, we would need highly invasive government rate regulation, not an ad hoc system of small-time private liability. Trying to regulate the entire mutual fund market with Section $36(\mathrm{~b})$ is like trying to bust up the nineteenth century railroad monopolies with common law unconscionability doctrine. There is thus no point to extending Section 36(b) to low-fee funds. Depending on how you view the mutual fund market, extending Section 36 (b) to low-fee funds is either too much or too little.

\section{F. Incoherence in the Standard of Liability}

The Gartenberg/Jones standard is also confused and incoherent, even in its application to comparatively high-fee funds. There are several problems.

\section{The Imaginary Nature of "Arm's Length Bargaining"}

The main problem is that the benchmark Gartenberg uses to assess fees is purely imaginary. It does not exist and so cannot be measured or observed. To put it roughly, the benchmark is the hypothetical bargain that a mutual fund would have struck with its adviser if the fund were truly independent from its adviser and had negotiated with the adviser at "arm's length." Specifically, the standard says the following:

[T] he test is essentially whether the fee schedule represents a charge within the range of what would have been negotiated at arm's-length in light of all of the surrounding circumstances. ... To be guilty of a violation of $\S 36(\mathrm{~b}), \ldots$ the adviser must charge a fee that is so disproportionately large that it bears no reason-

LEGAL STUD. 429 (2010) (showing in an experimental setting that students fail to heed standard warnings discouraging them from relying on past returns in selecting mutual funds); Sirri \& Tufano, supra note 71 (showing that inflows of new investment are primarily concentrated among funds with extremely high returns in the preceding year).

116. Javier Gil-Bazo \& Pablo Ruiz-Verdú, The Relation Between Price and Performance in the Mutual Fund Industry, 64 J. FIN. 2153 (2009) (showing that among actively managed funds, high-fee funds underperform low-fee funds even before accounting for fees). 
able relationship to the services rendered and could not have been the product of arm's length bargaining. ${ }^{117}$

The phrase "arm's length" appears twice. In both instances it serves as a kind of standard or benchmark. A fee is excessive if it departs too far from the "arm's length bargain."

The use of "arm's length bargaining" as a benchmark grows out of the Gartenberg court's belief, noted above, that no mutual fund is sufficiently independent of its adviser to truly negotiate at "arm's-length." This is why Gartenberg cautioned judges against relying on comparisons with other funds: other funds' fees cannot serve as adequate benchmarks, because no fund is truly independent of its adviser. Hence, a court must look instead at the fee that the fund would have negotiated if it had bargained at arm's length.

But here is the problem: no one knows what an arm's length bargain would be because no one has ever seen it. That was Gartenberg's whole premise: arm's-length bargaining does not exist in mutual funds. So how can it serve as a testable benchmark?

We have explained above the reasons why arm's-length-bargaining never occurs: since mutual fund investors can simply redeem, they never demand serious independence from the funds' directors, and the directors never fire the funds' advisers.

This is not the case in other contexts involving conflicted corporate fiduciaries. In other contexts, such as self-dealing by directors in ordinary companies, courts construct simulated arm's-length bargains by looking at other bargains that were actually struck at arm's length. That is, they look at the prices that other corporations paid for similar goods or services when those other corporations dealt at arm's length with unconflicted counterparties. If a widgetmaker buys widget components from one of its directors, for example, courts will look at what other widget-makers paid for those same components when they were not dealing with one of their own directors.

Such a comparative analysis is not possible in mutual funds, however. Gartenberg's claim - which was accurate-was that all mutual fund advisers are conflicted. So there are no other funds that charge arm's length bargains to serve as a basis for comparison. Plaintiffs have sometimes tried to proxy such a bargain by looking at fees for other types of collective investment funds, like hedge funds and pension funds. But these funds are not identical to mutual funds, and the fees they charge are not comparable to mutual funds' fees. Recent litigation focusing on sub-advisory fees has argued that it is a Section 36(b) violation for an advisor to provide sub-advisory services to a third party at a lower price than the price it charges in-house funds. ${ }^{118}$ Again, sub-advisory ar-

added).

117. Gartenberg v. Merrill Lynch Asset Mgmt., Inc., 694 F.2d 923, 928 (emphasis

118. See supra note 59 and accompanying text. 
rangements provide useful information, but they do not capture the full cost of running a fund and so represent a bargain about something other than the total fees.

So the question is this: if an arm's-length-bargain does not exist, how is it supposed to serve as a benchmark? How can courts measure something that is purely imaginary?

The most important problem is that imaginary things cannot be objectively perceived and measured. Calculating an "arm's-length mutual fund fee" is like measuring the height of a leprechaun. Most people have a vague sense that leprechauns and arm's-length mutual fund fees are small, but no one can say exactly how small, because no one has ever actually seen and measured one of these creatures.

We grappled with this problem first-hand in conducting our statistical analysis of excessive fee liability. The primary goal of that study was to assess whether excessive fee lawsuits were targeting funds that actually charged excessive fees or were simply targeting funds that were big or highly visible. This question was ultimately impossible to answer directly because we could not say what an excessive fee was. We could not test whether advisers with fees above the level of an arm's-length bargain were more likely to be targeted than advisers with fees below the level of an arm's-length bargain because we had no way of measuring an arm's-length bargain and no way of even knowing what it was. All we could do was compare funds to one another and try to assess whether funds with relatively high fees were more likely to be targeted than similar funds with relatively low fees.

Subsequent courts have dealt with the impossibility of the "arm's-lengthbargaining" question either by substituting a different question ${ }^{119}$ or by just throwing up their hands and saying that one of the parties-usually the plaintiff-has failed to answer the question. A good example is the District of Minnesota's grant of summary judgment in Gallus v. Ameriprise Financial. ${ }^{120}$

In that opinion, the court substituted a new question by asking not whether the funds' fees could have been negotiated at arm's length, but whether they actually were negotiated at arm's length. And Gallus made this new question easy to answer by equating arm's length bargaining with accurate disclosure. It asked simply whether the information the adviser disclosed to the fund's board of directors was accurate. ${ }^{121}$ Of course, accurate disclosure and arm's-length

119. This is a common and well-studied cognitive error: when faced with a difficult question, people often answer a different and easier one instead. DANIEL KAHNEMAN, THINKING, FAST AND SLOW 97-105 (2011).

120. Gallus v. Ameriprise Fin., Inc., 497 F. Supp. 2d 974 (D. Minn. 2007).

121. E.g., id. at 981 ("Viewing the facts in the light most favorable to Plaintiffs, the Court finds that no genuine issue of material fact exists regarding the disclosure and consideration of fall-out benefits that would suggest that the Board's fee-negotiation process could not have been an arm's-length one. Here, Plaintiffs do not dispute that the Board considered the reports that Defendants provided to them that expressly addressed the fall-out benefits when negotiating fees with Defendants."). 
bargaining are not the same thing: arm's-length bargaining requires one party not only to disclose information fully and accurately, but also to have no control or influence over her counterparty. ${ }^{122}$ Arm's length bargaining in its true sense is thus impossible between fund advisers and funds because funds cannot escape their advisers' control. That was Gartenberg's point. Therefore, by reframing the question to focus on the accuracy of disclosure, the Gallus court avoided the impossible task of trying to conjure what a bargain between a fund and its adviser would look like if the fund could free itself of the adviser's control.

The Gallus court also held, however, that the plaintiffs had failed at that very task. Faced with evidence that the adviser charged higher fees to its mutual funds than to its other clients (i.e., institutional investors who did not invest through mutual funds), the court observed that the plaintiffs had not proven what would have been required by an arm's length bargain. The plaintiffs' experts had proven the size of the fees, the court said, but not how those fees compared to the arm 's-length bargain against which they were supposed to be measured. ${ }^{123}$ Of course, no careful expert would ever pretend to have any idea what an arm's length bargain would entail, and the court offered no instruction on how to generate it.

The impossibility of Gartenberg's central question is especially a problem for those who believe that plaintiffs should occasionally win excessive fee suits. Gallus illustrates this clearly: where courts strictly insist on forcing plaintiffs to carry their burden of proof by answering the question Gartenberg actually poses, the plaintiffs must always lose because the question is impossible to answer.

\section{Undue Fixation on Adviser Profitability}

A further problem is that the Gartenberg standard unduly fixates on advisers' profitability. Perhaps because the "arm's-length bargain" standard was so difficult to apply, in the years after Gartenberg, courts developed a sixfactor test to guide the "arm's-length bargain" analysis. Among the factors are three that focus directly or indirectly on an advisers' profitability: the "profitability of the fund to the adviser-manager"; "fall-out benefits" to the adviser; and

122. Of course, the parties can try to simulate an arm's length bargain by constructing a committee of independent directors and so on, but they cannot achieve the reality of an arm's length bargain this way.

123. Gallus, 497 F. Supp. 2d at 981-82 ("Viewing the evidence in the light most favorable to Plaintiffs, the Court finds that no genuine issue of material fact exists regarding whether the fee schedules could not have been negotiated at arm's length. Plaintiffs do not dispute that breakpoints in the Funds' fee schedules served to share some economies of scale. Instead, Plaintiffs' argue that the breakpoints did not appropriately share economies of scale. But Plaintiffs do not establish why the existing breakpoints so inadequately shared the cost savings, such that the fee schedules could not have been the product of arm's-length bargaining. Plaintiffs' experts do not identify what amount of cost savings would have been appropriate, or why the amounts shared fall outside the range that could have been negotiated at arm's length. Accordingly, Plaintiffs' claims cannot survive summary judgment based on the economies-of-scale factor."). 
"economies of scale." 124 Fall-out benefits, as noted above, include benefits to an adviser other than fees. Economies of scale ask whether an adviser's costs remain steady even as a fund's size increases and the adviser's fee revenue correspondingly goes up.

There are two problems with fixating on adviser profitability. The first is that profitability has no direct impact on investors. What matters to investors are not profits, but fees. Investors do not suffer from high advisory profits, so long as the advisers charge low fees. An adviser who makes a lot of money by charging low fees is a cause for celebration, not concern.

The second problem with the fixation on profitability is that profitability is very difficult to assess. This deepens the problem, observed above, that plaintiffs can create factual disputes to survive motions to dismiss and motions for summary judgment, even when the defendants charge low fees. Advisers often have complex businesses with multiple mutual funds operating alongside private funds, separate accounts, and other lines of business. Assessing a mutual fund's profitability to an adviser requires disaggregating the costs of one fund from the costs of an adviser's other operations. But this is very difficult since the same employees and computer systems that serve one fund also typically serve many other funds and other lines of business. ${ }^{125}$ Advisers rarely attempt this kind of separate accounting for internal purposes, and they cannot reliably do so for litigation. The requirements that courts assess "fall-out benefits" and "economies of scale" deepen the problem.

Just as we did with the "arm's-length bargaining" standard, we grappled with the profitability analysis in our statistical study. And just as with the "arm's-length bargaining" standard, we came away with little sense of what to do. Since there is no clear definition of what it means for an adviser to be profitable and no data to allow comparisons across funds, the analysis was extremely difficult to perform in a satisfying way.

\section{G. Overall Inadequacy of Rewards for Plaintiffs' Lawyers}

A final problem is that Section 36(b)'s damage awards are too small to encourage meritorious suits. There are two limits on damages in Section 36(b). One is the prohibition against penalty awards discussed above. Another is a very strong statute of limitations that prohibits the recovery of any damages for periods more than one year prior to the filing of a Section $36(\mathrm{~b})$ complaint. ${ }^{126}$ Like the prohibition on penalties, this statute of limitations applies to the SEC

124. Krinsk v. Fund Asset Mgmt., Inc., 875 F.2d 404, 409 (2d Cir. 1989).

125. Murphy \& Cavoli, supra note 104 (describing the difficulty of disaggregating profitability for each fund for purposes of Section 36 (b) litigation).

126. 15 U.S.C. $\S 80 \mathrm{a}-35$ (b) (2012) ("No award of damages shall be recoverable for any period prior to one year before the action was instituted."). Damages can be recovered for fees charged while a lawsuit is pending, however. Gallus v. Ameriprise Fin. Inc., 561 F.3d 816, 824-25 (8th Cir. 2009). 
as well as to investors. These limitations are a problem because they apply without regard to a case's merit. Even the most meritorious cases yield small damage awards.

This is most evident in two important facts: (1) the highest fees are heavily concentrated among the smallest advisers; and (2) the smallest advisers almost never get sued under Section 36(b). Figure 3 illustrates.

Figure 3: Number of Funds in the Highest Fee Decile by Adviser Size Decile

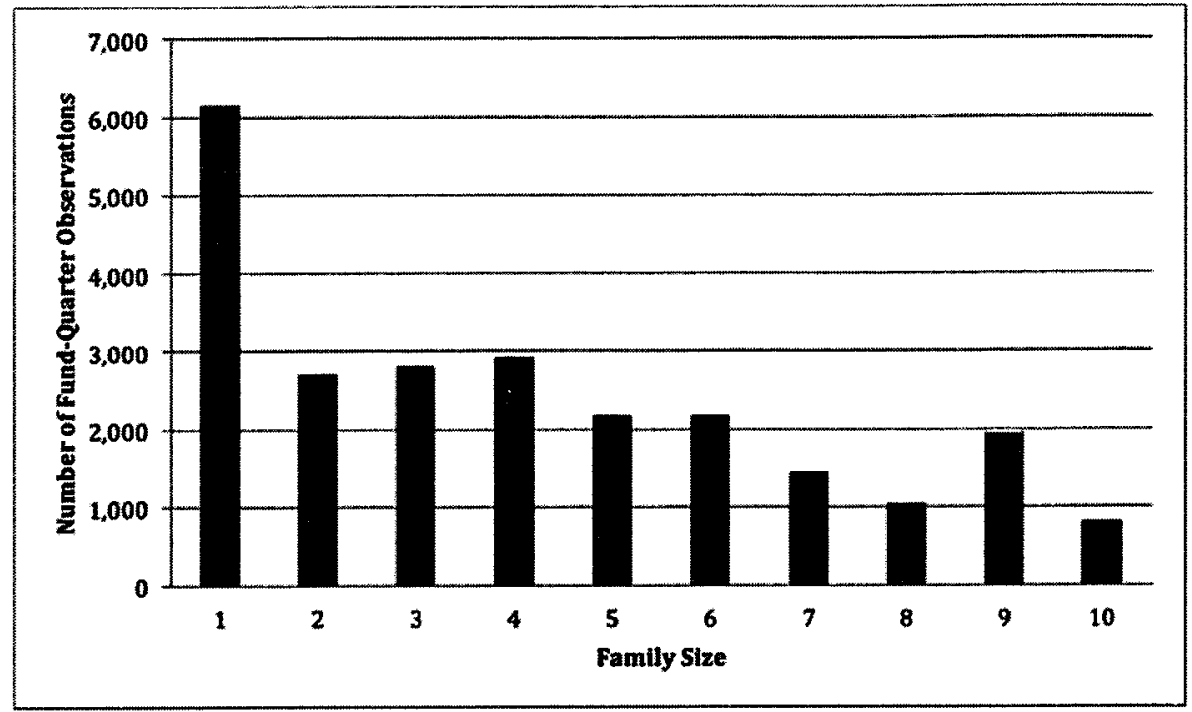

Figure 3 takes all funds whose fees placed them in the highest decile of their investing styles and sorts them by the sizes of their advisers. The Figure includes the most expensive $10 \%$ of money market funds, the most expensive $10 \%$ of S\&P 500 index funds, the most expensive $10 \%$ of technology funds, and so on. The horizontal axis sorts these highly expensive funds according to the size of the advisers who manage them. ${ }^{127}$ It divides advisers into ten deciles, so that advisers with the largest aggregate assets across all of their funds are on the right and those with the smallest assets are on the left. The vertical axis shows the number of top-fee-decile funds that appear in each of the ten advisersize deciles.

The Figure shows that high-fee funds are heavily concentrated among the smallest advisers. If high-fee funds were equally allocated across advisers, the tops of the bars in the Figure would be level. Instead, the bar is highest at the far left end, where the advisers are the smallest. This shows that funds with the

127. We measure size by the total amount of assets in all open-end mutual funds managed by the advisers. 
highest $10 \%$ of fees were heavily concentrated among the smallest $10 \%$ of advisers.

This is a problem because the smallest advisers are almost never targeted for excessive fee suits. Figure 4 shows the frequency of excessive fee suits by adviser size between 2000 and 2009. It divides all funds targeted by excessive fee suits into ten deciles based on the total amount of open-end mutual fund assets that their advisers managed. The vertical axis plots the number of funds in each decile of adviser size that were targeted for excessive fee suits. The Figure describes the group of funds managed by an adviser as a "family."

Figure 4: Number of Funds Targeted by Adviser Size Decile

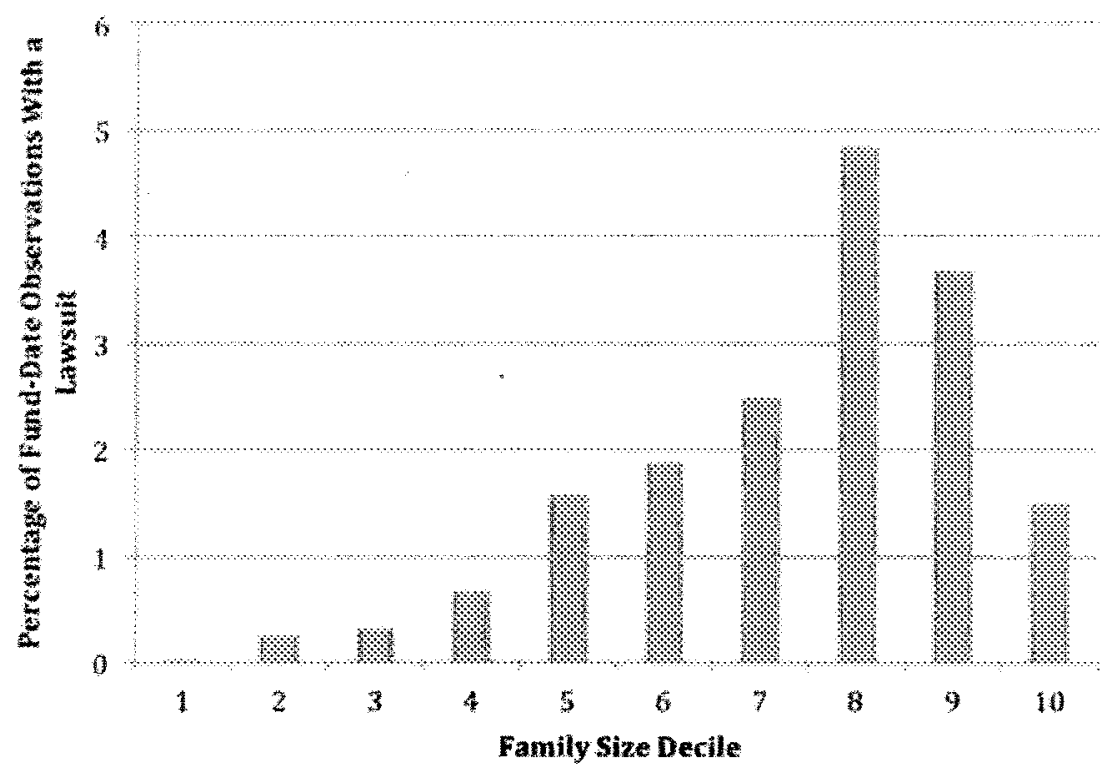

The implication of Figure 4 is striking: it shows that almost no funds in the smallest three adviser-size deciles were targeted for suits. Indeed, Figure 4 is almost a mirror image of Figure 3: although Figure 3 shows that the highestfee funds are concentrated in the smallest advisory families, Figure 4 shows that excessive fee suits are concentrated in the largest families.

This is because mutual fund advisers tend to charge fees as percentages of the total assets they manage. This means that total fee revenue and Section 36(b) damage awards are modest among small advisers. And when plaintiffs' attorneys' fees are calculated as a percentage of recoveries, plaintiffs' attorneys are unlikely to pursue small advisers. The draconian damages limitations in Section 36 (b) further deepen the problem. 
Some might argue in response that the targeting of large advisers is actually a good thing because large advisers can potentially do the most damage. We have two replies: first, suits against large advisers and suits against small advisers are not mutually exclusive. Even if suits against large advisers might be good, suits against small advisers would be good too. And yet suits against small advisers are simply not happening because the statute does not provide enough incentive to encourage them. Second, as between two advisers who both charge excessive fees, it is surely in the public's interest to punish the larger adviser, even if its fees are slightly less excessive than those of the smaller adviser. But this logic only works if the larger adviser's fees are indeed excessive. If the larger adviser's fees are moderate or low, then punishing the adviser makes no sense, regardless of how large it is.

\section{Reforming Excessive Fee Litigation}

The point of listing all of these flaws is not to call for excessive fee liability's elimination. Rather, the point is to call for reform. If excessive fee liability is ever to provide deterrence and compensation in a meaningful way at a reasonable cost to shareholders and advisers, then its problems must be fixed. We suggest the following possibilities for reform.

\section{A. Implement Excessive Fee Suits as Class Actions}

First, excessive fee lawsuits should proceed in the form of class actions rather than in their current form as not-quite-derivative actions. Class actions are already common in fraud-based lawsuits against mutual fund advisers, and they are clearly feasible. ${ }^{128}$ The class action form is a natural fit for the actual claims underlying Section 36(b) litigation because it makes clear that the real parties in interest are the aggrieved investors, many of whom may have departed the fund, rather than the fund itself. Converting excessive fee suits into class actions would solve several problems. First, it would eliminate the mismatch between recovery payments and the investors who deserve them. Since recoveries would go directly to investors, rather than to funds, investors would receive their appropriate shares of recoveries regardless of whether they redeemed or purchased before the recoveries were paid.

Second, it would solve the potential problem of multiple lawsuits over identical claims. If a judge certifies a group of shareholders as a class, a defendant who settles with the lead plaintiff of that class will gain protection against future claimants who might seek recoveries on behalf of the same class for the same time periods.

128. For example, the 2003 market timing scandal produced dozens of cases, pled as class actions. See, e.g., In re Janus Mut. Funds Inv. Litig, 310 F. Supp. 2d 1359, 1361 (J.P.M.L. 2004) ("[T]his litigation encompasses complex claims against multiple mutual funds by a vast number of plaintiffs/putative class members ...."). 
Third, settlements in these class actions would be public record and subject to judicial oversight, which would reduce the risk of collusive settlements in which defendants agree to settlements that mostly benefit plaintiffs' attorneys. $^{129}$

Finally, requiring class certification might place a hurdle in the way of plaintiffs' lawyers in the suits with least merit. For example, suits in which the complaint fails to identify which share classes, and therefore which fees, are at issue could be addressed at the class certification stage since the question of which investors paid which fees is relevant to identifying the relevant class.

\section{B. Harmonize the Treatment of Load Fees and Other Fees}

Congress or the SEC should also harmonize the treatment of sales loads and other types of fees, especially $12 \mathrm{~b}-1$ fees, as these two types of fees serve very similar functions and are regulated by FINRA in very similar ways. ${ }^{130}$ In our view, it is impossible to evaluate any of a fund's ongoing fees in isolation from sales loads since sales loads represent an important part of an investor's total bargain.

The best approach would simply be to eliminate the current exemption for sales loads in Section 36(b)(4). This approach should specify instead that judges must amortize load fees across a specified number of years when drawing comparisons between the annual costs of funds with and without load fees. This approach need not eliminate the concurrent regulation of sales loads under FINRA. Sales loads could continue to be regulated by both FINRA and Section 36 (b), just as Rule 12b-1 fees now are. Note also that the SEC could alter the FINRA rules to create a Section 36(b)-like standard of review if it so desired. The ICA gives the SEC the authority to supersede or directly change FINRA's sales load regulations. ${ }^{\text {I31 }}$

Section 36(b) litigation over sales loads would raise new issues that have not been addressed. Since sales loads are often used to provide commissions to brokers who sell the funds, the services provided by those brokers could potentially be put at issue under the Gartenberg factors. Moreover, since "load" funds are often substantially more expensive than "no-load" funds, load funds may attract a substantial amount of litigation under the revised statute. We do not regard such potential changes as regrettable. Research has raised questions about the value added by brokers, ${ }^{132}$ and load funds are often poor investment

129. Collusive settlements have been an issue of long-standing concern in corporate derivative litigation. See, e.g., John C. Coffee, Understanding the Plaintiff's Attorney: The Implications of Economic Theory for Private Enforcement of Law Through Class and Derivative Actions, 86 CoLUM. L. REV. 669, 672 n.9 (1986). The absence of judicial review in Section 36(b) settlements exacerbates this risk.

130. See supra Part II.C.

131. 15 U.S.C. $\S 80 \mathrm{a}-22$ (b)(2), (c) (2012).

132. Bergstresser, Chalmers \& Tufano, supra note 74 , at 4142 . 
options. Calling the highest-cost load funds to account for their fees is a perfectly reasonable extension of the policy motivations for Section 36(b).

\section{Add Penalties and Increase Recoveries}

We would also add penalties to the array of remedies available under Section $36(\mathrm{~b})$ and increase recoveries by lengthening the statute of limitations. Adding penalties would allow excessive fee liability to provide some degree of general deterrence by forcing advisers to do more than merely return their illgotten gains. Lengthening the statute of limitations would also encourage litigation by increasing the total recoveries available to investors and plaintiffs, particularly in suits against small advisers, among whom recoveries would otherwise be too small to make lawsuits profitable. It is important to encourage suits against small advisers, because these are the advisers who most frequently charge egregiously excessive fees. ${ }^{133}$

We reserve the questions of just how significant penalties should be and how long the statute of limitations should extend beyond the current one-year limitation. These questions require balancing potential concerns about strike suits with the need to make meritorious suits involving small funds worth pursuing. We note only that this challenge is hardly unique to fee litigation and that, in light of the discussion above, the current incentives to bring meritorious suits are clearly too low.

Of course, introducing penalties and increasing the statute of limitations will increase recoveries not just for meritorious suits, but for meritless ones as well. Absent other changes, this could decrease the average merit of Section 36(b) cases by increasing the incentive to settle marginal claims. This problem can be mitigated by our next set of proposals, which concern revising the standard of liability.

\section{Revise the Standard of Liability}

The Gartenberg/Jones standard should be eliminated and replaced with a new standard of liability that (1) cleanly exempts advisers with comparatively low fees and helps them resolve cases through summary judgment or dismissal and (2) provides a more coherent conceptual framework for assessing advisers with comparatively high fees.

\section{Exempt Advisers with Comparatively Low Fees}

We would first alter the standard to exempt advisers with comparatively low fees. This goal is important for the reasons we have given above: most of the mutual fund market is reasonably competitive, and the Gartenberg standard

133. See supra Part II.G. 
is so complex and ambiguous that it prevents even low-fee funds from winning on pretrial motions. Exempting low-fee advisers would become even more urgent if Congress adopted our proposal to increase the size of damage awards.

We think the best solution consists of two parts: (a) to require plaintiffs to allege that an adviser's fees are substantially above market norms and (b) to impose a heightened standard for these allegations at the pleading stage. We have in mind a heightened pleading standard akin to that imposed for securities fraud litigation under the Private Securities Litigation Reform Act of 1995, which requires complaints to "state with particularity facts giving rise to a strong inference that the defendant acted with the required state of mind."134 We would reformulate this standard for the mutual fund excessive fee context by imposing a requirement somewhat like the following: "plaintiffs must state with particularity facts that clearly indicate that the defendant received fees significantly in excess of the prevailing market fees charged by other providers for similar services to similar investment companies [i.e., funds] at similar times." Such a reform would probably be best implemented by statute, although it could be implemented by judicial doctrine as well.

Of course, there would be litigation about the application of this standard to particular cases. Defendants would have to spend money briefing the question of what precisely it means for fees to be "substantially above" prevailing rates and what it means for other funds to be "similar." There would nevertheless be substantial value to resolving these questions at the pleading stage, because defendants with below-market fees could litigate these questions before having to undergo discovery of evidence to satisfy Gartenberg's wide-ranging and ambiguous multi-factor test.

Plaintiffs can easily bear this burden without discovery. The Investment Company Act requires all mutual fund fees to be publicly disclosed. ${ }^{135}$ The fees have already been aggregated into user-friendly databases by several commercial data providers, including Morningstar and the University of Chicago's Center for Research in Securities Prices.

Of course, there are many technical challenges to devising a meaningful comparison between funds, but these challenges need not be overwhelming. The Gartenberg/Jones test already requires courts to compare a defendant's fees to those of its competitors (although it gives these comparisons little weight), and there are many ways to perform such comparisons. Commercial services such as Lipper and Morningstar have provided one possible option by subdividing the universe of existing mutual funds into dozens of categories by investing style. Lipper and Morningstar market these categorization systems to 
financial professionals who wish to draw comparisons among similar funds. Financial economists have developed algorithms to assess similarity as well. ${ }^{136}$

\section{Sharpening Liability for High-Fee Advisers}

With low- and moderate-fee advisers thus insulated from the Gartenberg/Jones standard's full multi-factor scrutiny, the next step would be to sharpen the standard of liability for high-fee advisers. Our primary recommendation is to abandon the Gartenberg/Jones test. As noted above, the "arm'slength bargaining" standard is impossible to apply honestly, since arm's-length bargains do not exist. And the six factors that are supposed to give the arm'slength bargain test structure are in practice nothing more than a clunky grab bag of factors with uncertain weights and purposes. In particular, the three factors that focus on adviser profitability ask the wrong question and generate too much expense in discovery.

We suggest instead a general standard that requires funds' fees to be "reasonable." This was the standard that Section 36(b)'s drafters initially proposed, ${ }^{137}$ and we think it is sensible. Though "reasonability" has the disadvantage of being vague, it has the benefit of not being completely imaginary. Unlike Gartenberg's "arm's-length bargaining" standard, reasonability does not give plaintiffs the impossible task of producing evidence about the size of something that does not exist.

To structure this reasonability standard, we propose a simplified array of factors that should be more easily observable than Gartenberg's six factors and will sharpen the focus on the right questions. The three factors that we propose are: 1) how a fund's fees compare to those of its peers; 2) whether the fund is a persistent underperformer; and 3) whether the fund provides ancillary services to justify high fees.

In our view, the first factor should be the primary one, and for funds that have fees comparable to peer funds in competitive sectors of the mutual fund market, it should be a dispositive. Whereas Gartenberg expressly deemphasized this factor, we would expressly emphasize it as the consideration of greatest importance. Besides requiring plaintiffs to plead that a fund's fees substantially exceed those of its peers, as we proposed above, we would also require that even when a fund has above-market fees, liability must be tied closely to the degree of excessiveness. Advisers whose fees are only mildly above

136. Stephen Brown \& William N. Goetzmann, Mutual Fund Styles, 43 J. FIN. ECON. 373 (1997) (proposing a method to classify mutual funds by their risk profiles); Sunil Wahal \& Albert Wang, Competition Among Mutual Funds, 99 J. FIN. ECON. 40, 44 (2011) (developing a way to measure the overlap in mutual funds' portfolios as a way of testing the effect of new mutual funds on the fees charged by their closest competitors).

137. S. 1659, 90th Cong. $\S 8$ (d) (1967) (proposing reasonableness standard in an early draft of the legislation that ultimately became Section 36(b)); SEC. \& EXCH. COMM'N, supra note 20, at 144 (proposing reasonableness standard in an SEC report that preceded legislative reforms). 
the norm should not be liable, but advisers whose fees are substantially above the norm should face very serious scrutiny indeed.

However, it will not do simply to declare that the advisers of the most expensive funds of every type have breached their fiduciary duties. There is a risk that such a process could become infinitely regressive. If the adviser of the highest-fee S\&P 500 index fund reduces its fee, for example, then what will happen to the adviser of the next highest-fee S\&P 500 index fund? That adviser would then have to reduce its fee, which would in turn force the third-highestfee adviser to reduce its fee, and so on down the line, until every adviser charges the same.

We suggest, therefore, that in addition to a fund's relative fee level, a court should also weight two other factors in cases where a fund is found to be high cost: first, is the fund a persistent underperformer? Although over- and underperformance should both be important in assessing the reasonability of fees, we focus in particular on underperformance because, while the number of mutual funds that regularly generate risk-adjusted returns in excess of a general market index is vanishingly small, the number of funds that regularly generate returns below the market is substantial due to high fees and other factors. ${ }^{138} \mathrm{~A}$ fund that languishes among the worst risk-adjusted performers should face extra scrutiny of its fees.

Second, does the fund provide ancillary services to investors that justify high costs? If the fund or its advisers provide benefits other than basic portfolio management that are not reflected in its investment returns but are costly to the advisers and beneficial to investors, then these services ought to weigh into a court's assessment of the fund's fees. Examples might include individualized investment advice for investors and check-writing services.

While these factors do not render the assessment of a Section 36(b) claim mechanical, they do much more than the Gartenberg standard to structure judges' reasoning. Moreover, these factors draw on information that is either publicly available or obtainable at low cost.

Combined with a more stringent pleading standard and a requirement that plaintiffs allege that a fund's fees are substantially above market, this test would produce a litigation environment in which funds that actually overcharge would be much more likely to be found liable and funds that do not overcharge could dispose of lawsuits at a lower cost than is currently possible. Indeed, we believe that many large mutual fund advisers might be willing to accept higher damages (as we suggest above) and a more stringent standard of liability in exchange for relief from nuisance litigation for comparatively low-fee funds.

138. Mark M. Carhart, On Persistence in Mutual Fund Performance, 52 J. FIN. 57, 57 (1997) ("The only significant persistence not explained is concentrated in strong underperformance by the worst-return mutual funds."). 


\section{A Mechanical Test of Liability?}

A further and more radical possibility would be to create a mechanical test of liability. FINRA already imposes a direct cap on sales loads, and we could imagine something similar for total expense ratios, which include all annual fees and expenses paid by a fund.

In particular, we envision a limit that adjusts in response to changes in market norms. The limit might be calculated, for example, as a function of the mean or median fee among all funds similar to the fund in question. A rule might calculate similarity in many ways. For example, it could mechanically measure the degree of overlap in two funds' portfolios. ${ }^{139}$ Since funds are required by law to publish their portfolios once a quarter, and since commercial data providers aggregate this data for analysis, this should be simple and easy to do. With this measure of similarity established, a cap could then be applied in several ways. It might take the form of a number of standard deviations away from the median among similar funds, for example, or even a multiple of the mean or a fixed number of percentage points above the mean.

An automatically adjusting cap would have the usual advantages of a bright-line rule, with relatively few of the disadvantages. The advantages would include clarity in application. The main disadvantage-imprecision in application-would be mitigated by the adjusting character of the cap. The cap would not be a single hard-and-fast line, but a marker that constantly fluctuates in response to changing market norms.

Note also that the cap would not have to be hard. It could serve instead as a starting point, not unlike the heightened pleading standard we propose above. Funds that fall below the mechanical line could be automatically exempted from liability, while funds above the line could be exposed to heightened scrutiny. Note also that, at least to some extent, an adjusting cap might face the infinite regression/recursion problem that we noted above. As funds reduce their fees, the cap will decrease, which will force further reductions in fees and so on. Creative thinking could solve this problem, however. The cap could be set above a floor, for example, so that it could not go below some specified level. While functionally simple, determining the actual fee thresholds for such a regulation requires difficult line-drawing. These difficulties are somewhat mitigated by the function of the cap as a safe harbor rather than a bar on fees in excess of the cap but would nevertheless present a regulatory challenge.

\section{Conclusion}

The current system of Section 36(b) litigation is so thoroughly broken that it cannot solve the problems it purports to address. But it is possible to see in

139. For an example of how to calculate portfolio similarity, see Wahal \& Wang, 
these flaws an opportunity for a win-win: our proposals would address the concerns of industry critics, who worry about overpriced funds, and also advisers, who see Section 36(b) suits as an ill-targeted nuisance. Our reforms would reduce the litigation exposure of advisers with low fees, increase deterrence for advisers with high fees, and ensure that recoveries go only to investors who actually deserve them.

Excessive fee liability is likely a permanent part of the mutual fund regulatory landscape. Ensuring that it provides the greatest benefit to investors at the lowest possible cost thus ought to be common ground for everyone who cares about mutual fund investors. 